\title{
Behavioural insights and business taxation: Evidence from two randomized controlled trials
}

\section{TTPI - Working Paper 2/2017 \\ May 2017}

\section{Nicholas Biddle}

Centre for Social Research and Methods, Australian National University

\section{Katja Fels}

RWI, University of Bochum

\section{Mathias G. Sinning}

Tax and Transfer Policy Institute, Crawford School of Public Policy, Australian National University, RWI and IZA

\section{Abstract}

This paper presents the findings of two Randomized Controlled Trials (RCTs) that were conducted in collaboration with the Australian Taxation Office (ATO). The first trial tests the effect of changes to letters (timing, social norms, color, and provision of information about charitable donations) on response rates of businesses, the timing of payments and the amount of tax debt payments. The second trial consists of two parts. The first part aims to raise awareness of the relevance of tax debt payment by changing internal guidelines used by field auditors. The second part focuses on studying the effect of changing the phone script used by desk auditors to offer assistance with payment arrangements and simplifying a follow-up letter. The findings of the first trial indicate that none of the treatments had a significant effect on any of the outcome measures considered. In contrast, the results of the second trial indicate that changing the phone script of desk auditors and simplifying the follow-up letter reduced the proportion of default assessments raised by the ATO significantly, suggesting that businesses are responsive to certain types of nudges. JEL Codes: C93, H25, H26.

Keywords: Tax compliance, business taxation, behavioural insights, nudging.

*We thank Valerie Braithwaite, Bob Breunig, Christian Gillitzer, Miranda Stewart and participants of the 5th Annual Workshop of the Tax Administration Research Centre (TARC) for helpful comments and suggestions. We also thank Lilia Arcos-Holzinger for outstanding research assistance. Biddle and Sinning gratefully acknowledge the financial support from the Australian Research Council (LP160100810). Fels gratefully acknowledges the support of a special grant ("Sondertatbestand") from the German Federal Ministry for Economic Affairs and Energy and the Ministry of Innovation, Science and Research of North RhineWestphalia. All correspondence to Mathias Sinning, Crawford School of Public Policy, College of Asia and the Pacific, JG Crawford Building \#132, Lennox Crossing, The Australian National University, Canberra ACT 2601, E-mail: mathias.sinning@anu.edu.au, Tel: +6126125 1284. 
Tax and Transfer Policy Institute

Crawford School of Public Policy

College of Asia and the Pacific

+61261259318

tax.policy@anu.edu.au

The Australian National University

Canberra ACT 0200 Australia

www.anu.edu.au

The Tax and Transfer Policy Institute in the Crawford School of Public Policy has been established to carry out research on tax and transfer policy, law and implementation for public benefit in Australia. The research of TTPI focuses on key themes of economic prosperity, social equity and system resilience. Responding to the need to adapt Australia's tax and transfer system to meet contemporary challenges, TTPI delivers policy-relevant research and seeks to inform public knowledge and debate on tax and transfers in Australia, the region and the world. TTPI is committed to working with governments, other academic scholars and institutions, business and the community.

The Crawford School of Public Policy is the Australian National University's public policy school, serving and influencing Australia, Asia and the Pacific through advanced policy research, graduate and executive education, and policy impact. 


\section{Introduction}

Tax non-compliance is a serious concern to governments worldwide. ${ }^{1}$ Outstanding tax debt payments undermine the ability of governments to provide public services and pose a threat to the perceived fairness of the tax system. According to the latest Internal Revenue Service (IRS) estimates for the years 2008 to 2010, the average annual tax gap in the US amounted to $\$ 458$ billion - 18.3 percent of the total revenue owed (IRS, 2016). Despite substantial collection efforts of the IRS, a considerable part of this tax liability will never be paid. Even in countries with a relatively small population like Australia, collectable tax debt is $\$ 19.5$ billion annually (ATO, 2015). The major share of this amount can be attributed to businesses who often owe more than twice as much as individual taxpayers (Ariel, 2012). Businesses and self-employed persons have more opportunities to evade taxes because they are less often subject to tax deducted at the source of their payments and to third party reporting (Thomas, 2013). As a consequence, only about half of business non-compliance is detected (Kamleitner et al., 2012). Business taxpayers have also been found to have a lower tax morale, ie. a lower intrinsic willingness to meet their tax obligations (Torgler, 2007). ${ }^{2}$ Consequently, they constitute a highly relevant target group for tax collectors trying to increase voluntary tax compliance.

Despite the substantial contribution of business taxpayers to government revenue, research on the behavioral foundations of business tax compliance is rather scarce (Hallsworth, 2014; Gangl et al., 2014; Arcos-Holzinger \& Biddle, 2016) for three main reasons: First, due to its nature, it is difficult to observe tax non-compliance. In the face of potential punishment, evading taxpayers will try to conceal their actions and are unlikely to respond correctly even in anonymous surveys (Slemrod, 2016). This behavior is even more likely for businesses because there may be more than one person responsible for filing. Second, most tax administrations refrain from engaging in field evaluations testing the effect of alternating policies to improve compliance behavior. Third, most trial research on tax behavior focuses on one intervention only rather than analysing multiple approaches to influence the same decision process. Randomized controlled field experiments have emerged only very recently as a tool to investigate tax compliance (Wenzel \& Taylor, 2004; Dwenger et al., 2016). Most of these experiments

\footnotetext{
${ }^{1}$ Our understanding of tax non-compliance comprises both willful and inadvertent avoidance of tax obligations. Our study only allows us to observe the outcome but not the taxpayers' intent (Slemrod, 2007).

${ }^{2}$ Other studies find no difference in tax morale between business owners and employees in terms of personal norms regarding tax honesty and the obligation to obey with the law, but a greater share of business owners admits to have evaded tax payments (Ahmed \& Braithwaite, 2005).
} 
have focused on individual taxpayers, while business taxpayers remain understudied (Gangl et al., 2014; Hallsworth, 2014; Ariel, 2012).

To fill this gap, this paper presents the results of two Randomized Controlled Trials (RCTs) that target business tax compliance. The trials were designed and implemented in collaboration with the Australian Taxation Office (ATO), the main tax collecting body in Australia. The participating businesses were not aware of the experimental nature of the interventions and outcome measures are actual tax return data. With this setup, our study aims to generate "external validity at the highest level", which Wenzel \& Taylor (2004) pose for field experiments in the tax context. ${ }^{3}$ Our study advances the literature by applying non-deterrence approaches to business tax compliance (instead of individual tax compliance). By having the interventions implemented by the ATO and observing actual tax compliance behavior, the field test preserves realism and is of high relevance to researchers and policymakers alike.

The ATO is responsible for collecting most Commonwealth taxes from individuals and businesses, including income tax, Goods and Services Tax (GST), Superannuation Guarantee and Higher Education Loan Programme (HELP). Taxation in Australia is based on self-assessment combined with payment and enforcement systems. Businesses are required to report their tax obligations and entitlements to the ATO by lodging a quarterly (or monthly, depending on turnover) business activity statement (BAS). The payment of outstanding tax liabilities is subject to specified time schedules. While the majority of taxpayers pay their taxes on time, challenges in the economy, trade debts, issues with business solvency and, potentially, administrative and compliance factors, all contribute to delays and failures in tax payment.

The results presented in this paper are based on two trials that were conducted together with the ATO in 2016 during the start phase of an ongoing research project. The first trial - the BAS Revision Trial - focuses on businesses paying the correct amount of tax. If transactions vary considerably from normal business activity, businesses may receive a personalized letter from the ATO asking them to review their BAS and to notify the ATO if an error occurred.

\footnotetext{
${ }^{3}$ According to Gerber \& Green (2012), field experiments (or trials) are "randomized studies that are conducted in real-world settings." According to the authors, lab and field experiments are two ends of a spectrum, with four criteria that can be used to distinguish them. The trial described here meets the external validity requirement on all four of these dimensions: Authenticity (whether the treatment used closely approximates the types of interventions that are likely to occur in the real world); Participants (whether the members of the treatment and the control group resemble the actors who would normally encounter these interventions); Context (whether the settings within which the subjects receive the intervention are similar to the context of interest); and Outcomes (whether the outcomes being measured resemble the outcomes of theoretical or practical interest).
} 
The aim of the trial was to test the effect of changes to this letter on response rates of taxpayers, the timing of payments and the amount of payments of liabilities. The interventions were: (1) changing due dates, (2) addressing social norms, (3) using a different color, and (4) informing taxpayers about tax-deductible donations. Each intervention involved a single change in letter content or style.

The second trial studies compliance with employer obligations (the Employer Obligations Trial). Employers in Australia have to transfer money into different government funds to fulfil their tax and superannuation obligations. Field auditors and desk auditors of the ATO regularly conduct payment conversations with business taxpayers and send out a notice of audit to check compliance with employer obligations. The trial consists of two parts. The first part assesses the effect of changing internal guidelines used by field auditors to raise awareness of the relevance of tax debt payments. The new guidelines emphasize the importance of payment conversations with taxpayers. The second part focuses on studying the effect of simplifying a letter and changing the phone script of desk auditors to offer taxpayers a direct connection to an ATO officer to work out a suitable payment plan. Study outcomes include debt collection measures, the duration of case cycles, and information about whether a default assessment was raised by the ATO during the audit (an indicator that taxpayers did not comply with their filing obligation).

The empirical findings of the BAS Revision Trial indicate that none of the four treatments had a significant effect on any of the outcome measures considered in our analysis. Several factors may be responsible for this result. First, the differences between treatment and control letters were relatively small. Second, the sample size (up to 589 observations in each treatment and control group) may have been too small to detect an effect. Third, despite these limitations, it is possible that businesses are simply not very responsive to this type of intervention. While researchers have recently found significant effects of nudges on the behavior of individual taxpayers (Hallsworth et al., 2017; Bott et al., 2014), we still know very little about behavioral responses of businesses.

A different picture emerges in the Employer Obligations Trial. We find that changing internal guidelines used by field auditors (first treatment) reduces the amount owed by the taxpayer at the end of the case cycle but the effect disappears when we control for differences in observed characteristics between the treatment and the control group. We also find that 
simplifying a letter and changing the phone script used by desk auditors (second treatment) reduces the proportion of default assessments raised by the ATO substantially (more than 20 percentage points). The effect remains significant even when we control for observed characteristics. Overall, the results suggest that our treatments led to some improvement, indicating that businesses are responsive to nudges like simplification and the provision of help with setting up an individualized payment schedule.

The remainder of this paper is structured as follows. Section 2 briefly reviews the related literature. Section 3 presents the research design, data collection, and results of the first trial. Section 4 does the same for the second trial. Section 5 concludes and discusses our findings.

\section{$2 \quad$ Related Literature}

Academic research in tax evasion and enforcement has "exploded" since the beginning of the new millenium (Slemrod, 2016). RCTs have emerged recently, in addition to studies that make use of the wider availability of administrative tax records, as a crucial methodology for identifying effects on taxpayer behavior (Hallsworth, 2014). In an RCT, researchers randomly assign control and treatment conditions to agents acting in real-world situations. This approach offers the prospect of isolating the causal effect of a treatment (List \& Metcalfe, 2014) while at the same time advancing the understanding of theoretically derived hypotheses in a real-world setting.

Interventions tested in previous tax compliance trials can be classified into two categories. ${ }^{4}$ Traditionally, tax evasion has been explained by a deterrence model: Risk-averse taxpayers make a decision about tax evasion by comparing the costs (which depend on the probability of being detected and the legal punishment) to the benefits (Allingham \& Sandmo, 1972). Interventions that make the probability of detection and the severity of punishment more salient are called "deterrence interventions". More recently, researchers have started to apply behavioral insights to tax (non-)compliance. This so-called "non-deterrence approach" emphasizes that social norms, perceptions of fairness, tax morale, and the provision of public goods play an important role in decision-making processes of taxpayers (for an overview see Hallsworth, 2014). Interventions that make use of changes in the "choice architecture" (Thaler \& Sun-

\footnotetext{
${ }^{4}$ In addition to the empirical literature based on results from field trials, there is a considerable amount of research making use of survey data in order to shed light on the complex issue of business tax compliance (see, for example, Ahmed \& Braithwaite, 2005; Gangl et al., 2013; Tan \& Liu, 2016; Woodward \& Tan, 2015).
} 
stein, 2008), e.g. by framing information differently, addressing social norms or simplifying background information, fall into this category.

The widespread adoption of the deterrence model of regulation by administrations is mirrored by the empirical evidence. An extensive amount of work has been done evaluating deterrence strategies, and almost all existing experimental studies suggest that these approaches are successful in improving tax compliance (Coleman, 1997; Slemrod et al., 2001; Wenzel \& Taylor, 2004; Wenzel, 2006; Hasseldine et al., 2007; Iyer et al., 2010; Kleven et al., 2011; Fellner et al., 2013; Harju et al., 2014; Gangl et al., 2014; Perez-Truglia \& Troiano, 2015; Dwenger et al., 2016; Dyreng et al., 2016). ${ }^{5}$ However, some studies point to the phenomenon that deterrence approaches may backfire for certain subgroups of taxpayers. Slemrod et al. (2001), for instance, find that while a letter informing taxpayers that they had been selected for an audit increased reported income among low- and middle-income earners, the letter had the opposite effect on high-income earners with high evasion possibilities. Mendoza et al. (2017) find that there is a U-shaped relationship between auditing level and tax compliance: Compliance increases until a certain auditing level is reached, and decreases beyond that level. While the majority of deterrence research focuses on individual taxpayers, first evidence suggests that businesses are also responsive to interventions that increase the salience of audit probabilities (Harju et al., 2014; Gangl et al., 2014). ${ }^{6}$

The other strand of the experimental tax compliance literature focuses on non-deterrence interventions, in particular on social norms and moral appeals (Schwartz \& Orleans, 1967; McGraw \& Scholz, 1991; Blumenthal et al., 2001; Torgler, 2004; Wenzel \& Taylor, 2004; Wenzel, 2005a; Coleman, 2007; Hasseldine et al., 2007; Fellner et al., 2013; Torgler, 2013; Bott et al., 2014; Dwenger et al., 2016; Hallsworth et al., 2017). Many previous studies do not find an effect of moral persuasion or an emphasis of social norms on the behavior of individual taxpayers (Blumenthal et al., 2001; Torgler, 2004; Wenzel, 2005a; Fellner et al., 2013). Only a few recent studies discover an effect of addressing social norms. Hallsworth et al. (2017), for instance, run an RCT with 200,000 taxpayers in the United Kingdom and find that informing

\footnotetext{
${ }^{5}$ In Iyer et al. (2010), two deterrence treatments show no significant effect but the authors conclude that the treatments are effective because they find a significant effect of the pooled treatments on tax compliance.

${ }^{6} \mathrm{~A}$ related literature on tax compliance is emerging in low- and middle-income countries (see, for example, Castro \& Scartascini, 2015; Pomeranz, 2015; Ortega \& Scartascini, 2015; Khan et al., 2016; Del Carpio, 2013; Shimeles et al., 2017). The findings of these studies cannot be easily transferred to high-income countries like Australia because distrust in governmental structures and a low capacity of enforcing regulations are crucial drivers of non-compliance in these countries.
} 
people that they belong to the minority of taxpayers who have not payed their taxes on time significantly decreased the time to payment of the outstanding liability. Bott et al. (2014) show that moral appeals seem to affect taxpayers in Norway who had been identified by the tax collector as being likely to underreport their income. After receiving a moral appeal, the reported average foreign income in the treatment group doubled compared to the control group. Similar results of moral appeals have been found earlier by Schwartz \& Orleans (1967) and Hasseldine et al. (2007). In contrast, Dwenger et al. (2016) show that in the case of a zeroaudit-probability for church taxes in the German state of Bavaria, baseline compliers increase their compliance after receiving social and monetary rewards, whereas baseline non-compliers reduce their compliance even more. Similarly, interventions informing taxpayers about public services that are being funded by their taxes indicate that such an approach may also backfire (Torgler, 2013).

Despite the vast amount of research targeting individual taxpayers, we still know very little about the potential reactions of business taxpayers to non-deterrence interventions. This is unfortunate because it appears likely that business taxpayers are quite different from individual taxpayers. Businesses may have several actors with varying degrees of responsibility for the tax filing process, making it harder to relate to personal factors (Ariel, 2012). Moreover, while individual taxpayers often receive a refund when filing their tax return, the majority of businesses does not (Thomas, 2013). These differences between individual and business taxpayers may have important implications for tax compliance rates. ${ }^{7}$

Field trial evidence on business tax compliance within the non-deterrence framework is limited and the results are rather mixed. We are aware of only two studies that examine business tax compliance in this framework. ${ }^{8}$ Wenzel (2006) evaluates reminder letters of the ATO to businesses who failed to file their BAS in time. In an RCT with about 2,000 cases, two treatment letters were compared to a control letter. The two treatment letters were designed to provide additional information to taxpayers (informational letter) or to assure taxpayers that they were not suspected of being deliberately dishonest and to express sympathy and

\footnotetext{
${ }^{7}$ Several studies find that prospect theory is a good predictor of compliance: Taxpayers who claim a refund tend to view the potential outcome as a gain, which makes them more likely to file. Taxpayers being confronted with a tax debt (such as outstanding GST payments to the tax collector) act more risk-seeking in the face of a potential loss and will be more likely to exhibit non-compliant behavior (Thomas, 2013).

${ }^{8}$ Additionally, preliminary work by the Irish Office of the Revenue Commissioners (2017) indicates that a social norms letter to taxpayers with an outstanding value-added tax debt increased engagement with the agency to arrange payment.
} 
understanding (interpersonal letter). Both treatment letters lead to a higher probability of businesses filing within the deadline communicated in the letters compared to the control letter. In contrast, the findings of Ariel (2012), which are based on about 700 businesses in the treatment group and about 2,900 businesses in the control group, do not suggest that moral persuasion leads to an improvement in business tax compliance in Israel. The results even indicate that targeting businesses with moral persuasion can have adverse effects: After receiving a letter that emphasized the societal consequences of not paying taxes, businesses in the treatment group asked for significantly higher deductions than businesses in the control group. Overall, the limited evidence on business tax compliance in a non-deterrence framework highlights a need for further research.

We contribute to the emerging literature on tax compliance in several ways. First, we provide systematic evidence on the effectiveness of a range of interventions, which allows us to draw inferences about policies that are likely to work in similar contexts. Tax administrators have "too often" (Wenzel \& Taylor, 2004) relied on unsystematically gathered intelligence and untested assumptions about the regulated behavior of taxpayers. ${ }^{9}$ Second, our findings are based on actual administrative tax records of businesses in Australia. Prior research on business tax compliance has focused predominantly on qualitative statements and theoretical considerations. Third, we advance the tax compliance literature by applying non-deterrence concepts to businesses rather than individuals. We cannot simply assume that businesses are as responsive to interventions in a non-deterrence framework as individual taxpayers. Finally, we provide pioneering evidence on the role of simplification as an effective tool for improving business tax compliance. Our findings also add to the existing doubt in the literature regarding the effectiveness of nudges like social norms when targeting business tax compliance.

\section{BAS Revision Trial}

Businesses in Australia collect the Goods and Services Tax (GST) for the government. They are required to report their tax obligations and entitlements to the ATO by filing a monthly or quarterly BAS. Businesses receive a letter from the ATO asking them to review their GST claim if the transactions they report deviate substantially from normal business activity. The

\footnotetext{
${ }^{9}$ The ATO refrained from randomly assigning taxpayers to a non-treatment group in the past because of potential revenue losses associated with certain interventions (Braithwaite, 2005).
} 
$B A S$ Revision Trial tested four modified versions of the original letter incorporating behavioral insights. On 12 November 2015, the ATO sent out 2,938 letters to four treatment groups and a control group. Randomization was based on a random variable generator in Stata, using a random choice of the underlying seed. The data collection for the trial ended in February 2016, and de-identified data were made available by the ATO after the registration of the trial in the AEA RCT Registry on 24 February 2016. ${ }^{10}$

\subsection{Interventions}

The interventions of the BAS Revision Trial are: (1) Timing: changing the due date from 30 November 2015 to 14 December 2015, (2) Social Norms: changing the heading of the letter from "You need to review your GST refund" to "Our tax system works because people do the right thing", (3) Color: changing the color of heading and subheading from blue to orange, and (4) Warm Glow: informing taxpayers about tax deductible donations. Each intervention involved a single change in letter content or style. Sample letters are included in Appendix A.

In a grey-shaded box, taxpayers were informed that their GST refund claim may be incorrect and they were asked to review their records and revise any claims by the given due date. The Timing treatment allowed two additional weeks of time for filing a revision. Previous work has identified timing of interventions as an influential factor guiding subsequent behavior. ${ }^{11}$ For businesses that are required to put effort into revising their BAS, changing the due dates may have two opposing effects. On one hand, extending the deadline reduces time pressure. A longer time frame might be more realistic and therefore increase the number of businesses that manage to file a revision. On the other hand, a deadline that is further away may decrease the feeling of urgency and reduce salience of the letter, thereby reducing the number of businesses reviewing their BAS.

Appeals to social norms have been shown to have a positive effect in various domains, including individual tax compliance (see Bobek et al., 2013, for an overview), energy conservation (Ferraro et al., 2011; Seyranian et al., 2015; Tiefenbeck et al., 2013) and charitable giving

\footnotetext{
${ }^{10}$ The trial was registered in the AEA RCT Registry (AEARCTR-0000833, https://www. socialscienceregistry.org/trials/833), and the analysis of the trial data used in this paper received Human Ethics approval from the ANU (ethics protocol number 2016/029, title: Testing the Effect of Tax Office and Taxpayer Interactions on the Integrity of Refund Claims).

${ }^{11}$ See, for example, the "Easy, Attractive, Social and Timely" (EAST) framework of the Behavioral Insights Team in Great Britain (Hallsworth, 2014).
} 
(Frey \& Meier, 2004; Martin \& Randal, 2008). Social norms refer to a behavior that a group of people collectively perceives as moral (Wenzel, 2005b). Feelings of guilt and shame make noncompliance to this norm costly, even when a violation of the norm is not detected by others. However, the effect of social norms depends on the recipients' prior beliefs (Hallsworth, 2014). Studies found an increasing compliance when social norms were salient in the tax compliance decision and after individuals had an opportunity to update their beliefs about these norms (Arcos-Holzinger \& Biddle, 2016). The aim of our Social Norms treatment is to increase the salience of a moral duty to "do the right thing".

Changing the color of heading and subheading from blue to orange may increase the sense of urgency and thereby contribute to a higher compliance rate. The change in layout was inspired by evidence suggesting that certain colors make messages more salient and may increase response rates (Edwards et al., 2009). Unfortunately, the color treatment tested as part of this trial is not very strong because the ATO was only willing to agree to a rather small change in layout.

Our last treatment aims to test whether providing information about the possibility of charitable giving can trigger a warm glow effect or induce an application of social norms,

which may in turn affect the willingness to comply with the rules. Theoretical models suggest that individuals can either contribute to a public good because they are purely altruistic or because they derive utility from giving per se, which is referred to as "warm glow" (Andreoni, 1990). Moreover, work by Ariely (2008) demonstrates that individuals behave differently depending on whether they apply social or market norms. If charitable donations are linked to an emotional state in which individuals make decisions according to social norms, then they may also be more inclined to "do the right thing" with regards to tax compliance.

\subsection{Empirical Strategy and Data}

Our analysis is based on estimating separate regression models to compare the outcome measures of members of one of the four treatment groups to those of the control group. Each of the four analysis samples includes $N_{t}$ members of treatment group $t, t=1,2,3,4$, and $N_{0}$ members of the control group. Given this setup, the general strategy for studying the effect 
of treatment $t$ on an outcome measure of interest is to estimate the following model:

$$
Y_{i}^{t}=\beta_{0}^{t}+\beta_{1}^{t} T_{i}^{t}+\varepsilon_{i}^{t}, \quad i=\underbrace{1,2, \ldots, N_{0}}_{\text {control group }}, \underbrace{N_{0}+1, N_{0}+2, \ldots, N_{0}+N_{t}}_{\text {treatment group } t}, \quad t=1,2,3,4,
$$

where $Y_{i}^{t}$ refers to one of the outcome measures of taxpayer $i . T_{i}^{t}$ is the treatment indicator for the comparison of treatment group $t$ and the control group, and $\varepsilon_{i}^{t}$ is the model error term. The parameter of interest is $\beta_{1}^{t}$, the (unconditional) average treatment effect. The sample sizes of the treatment and control groups are: $N_{0}=589, N_{1}=585, N_{2}=589, N_{3}=588$, $N_{4}=587$. However, most of our regression models are based on subsamples because our outcome measures include missing values.

We use the following continuous outcome measures in our analysis: (i) The total amount of payments made by the taxpayer after 12 November 2015, (ii) the net amount of GST on the original BAS minus the amount declared on the revised BAS, (iii) the revised net amount of all taxation items (including GST, withholding tax associated with certain payments to employees and other taxes declared on the BAS). We also use binary outcome measures indicating whether (iv) a revision was lodged by the taxpayer, whether (v) the GST amount declared on the revised BAS was in favor of the ATO or (vi) the taxpayer or (vii) whether there was no change after the revision, and variables indicating whether (viii) the net amount of all taxation items declared on the BAS was in favor of the ATO or (ix) the taxpayer or (x) whether there was no change after the revision. Finally, two count data variables are used as outcomes measures: (xi) the number of payments made by the taxpayer after 12 November 2015 and (xii) the number of days until the first payment was received from the taxpayer after 12 November 2015.

In addition to equation (1), we estimate separate models including a set of control variables. Given the notation above, these models may be summarized by the following equation:

$$
Y_{i}^{t}=\gamma_{0}^{t}+\gamma_{1}^{t} T_{i}^{t}+X_{i}^{t} \gamma_{2}^{t}+\eta_{i}^{t}, \quad i=1,2, \ldots, N_{0}+N_{t}, \quad t=1,2,3,4
$$

where $X_{i}^{t}$ is a vector of control variables and $\eta_{i}^{t}$ is the model error term. The parameter $\gamma_{1}^{t}$ is the (conditional) average treatment effect after controlling for $X_{i}^{t}$. The data provided by the ATO include a number of potential control variables (see Appendix C for a complete list). Table 1 reports the means of these variables and the $p$-values that refer to the comparison of means between treatment and control groups. The numbers in Table 1 reveal that most of 
the means do not differ significantly between treatment and control groups, indicating that the random assignment of taxpayers to treatment and control groups was highly effective. Significant differences at a $1 \%$ level are only observed in three cases. Specifically, members of treatment group 3 are slightly less likely to belong to the agricultural sector than members of the control group. Moreover, members of treatment group 4 are slightly less likely to belong to a trust and to reside in Queensland than members of the control group. In total, there are 11 cases in which sample means of treatment and control groups differ significantly at a $5 \%$ level and we consider the corresponding variable groups in equation (2) to control for these differences. ${ }^{12}$

[Table 1 about here.]

In the following, we use a linear regression model as a starting point to estimate equations (1) and (2). To account for the non-linear nature of some of our outcome measures, we estimate Probit models for binary dependent variables and Poisson regression models for count data variables. We also perform a survival analysis to study differences in the number of days until the first payment was received between treatment and control groups.

\subsection{Results}

Table 2 presents the average treatment effects obtained from a linear regression model without control variables. The estimates reveal that the four treatments had no significant effect on any of the outcome measures considered in our analysis, suggesting that changes in due dates, social norms, a different color and the provision of information about tax-deductible donations had no effect on how businesses behaved.

[Table 2 about here.]

We also estimate equation (2) via OLS but the inclusion of control variables does not change our results qualitatively. The results are not presented here and are available from the authors on request. Instead, we present the estimated marginal effects of a binary Probit model including control variables in Table 3. (We do not present the results without control variables because they are almost identical to the OLS estimates.) The estimates in Table 3

\footnotetext{
${ }^{12}$ We are unable to include total profit/loss information in our conditional model when comparing treatment group 3 to the control group due to insufficient observations.
} 
do not differ qualitatively from those presented in Table 2, indicating that our findings do not depend on the functional form of the regression model.

[Table 3 about here.]

Table 4 includes the marginal effects of a Poisson regression model including control variables. (Again, we do not present the results without control variables because they are almost identical to the OLS estimates.) The Poisson regression results confirm that there are no significant effects of the four treatments on the number of payments made by the taxpayer and the number of days until the first payment was received.

[Table 4 about here.]

We also perform a survival analysis of the number of days until the first payment was received from the taxpayer. In all cases, log-rank tests for the equality of survivor functions indicate that differences in survivor functions of treatment and control groups are not statistically significant, suggesting that the four treatments had no effect on the number of days until the first payment was received. The $p$-values associated with the log-rank tests were larger than 0.3 in all cases, suggesting that the differences in survivor functions are insignificant, even at a $30 \%$ level.

In sum, we find no evidence for an effect of the four treatments on any of the outcome variables considered in our analysis. Several factors may be responsible for this result. First, the differences in treatment and control letters were rather small as the ATO had already made use of behavioral insights (albeit in a non-experimental setting) to change the form of the letters. For example, the control letter is almost identical to the letter in which the color was changed in a few places. Even though research indicates that compliance is affected by apparently small details such as timing, framing, and visual presentation (Hallsworth, 2014), the nudges may have been too small to actually induce a behavioral change.

Second, the relatively small sample size leads to imprecise estimates, which makes it difficult to detect significant effects. Power calculations indicate that our full sample would have allowed us to detect a 3.5-percentage point increase in the proportion of revisions lodged by the taxpayer (given $80 \%$ power and a significance level of 5\%). Detecting an increase by, say, 2-percentage points would have required a much larger sample (about 8,000 observations in total). 
Despite these limitations, it is possible that businesses are simply not very responsive to this type of intervention. Up to now there is not much evidence on behavioral responses in the context of business taxation. Our findings suggest that non-deterrence interventions, such as timing and framing, may not be effective when targeting businesses. The following section presents the results of a second trial, which focuses on a different set of interventions.

\section{Employer Obligations Trial}

In addition to their tax obligations, businesses in Australia have to contribute to their employees' superannuation funds, collect pay as you go (PAYG) withholding amounts from certain payments made, and report fringe benefit tax (FBT). The ATO regularly checks whether these employer obligations are met. Field auditors and desk auditors conduct payment conversations with businesses and send out a notice of audit to check compliance with employer obligations. The first part of the Employer Obligations Trial involves changes to the internal guidelines of field auditors. The second part of the trial tests the effect of simplifying a letter in combination with changes to the phone script used by desk auditors. The phone scripts and the first page of the treatment and the control letter are provided in Appendix B. Random assignment of auditors to treatment and control group is based on a random variable generator in Stata, using a random choice of the underlying seed. The trial started on 29 February 2016. Deidentified data were made available by the ATO after the registration of the trial in the AEA RCT Registry on 14 July $2016 .{ }^{13}$

\subsection{Interventions}

The first part of the Employer Obligations Trial focuses on changes in guidelines used by field auditors for payment conversations. The intervention draws on international experience including a development in tax collection and debt recovery called Payment Thinking, pioneered by the Swedish Tax Agency (OECD, 2014; STA, 2005) and based on seminal work on tax compliance (Braithwaite, 2003). Payment Thinking is a unified approach to tax collection that is viewed as a part of all activities of the tax agency. It aims to achieve comprehensive

\footnotetext{
${ }^{13}$ The trial was registered in the AEA RCT Registry (AEARCTR-0000838 (https://www . socialscienceregistry.org/trials/838), and the trial data used in this paper received Human Ethics approval from the ANU (ethics protocol number 2016/375, title: Testing the Effect of Tax Office and Client Interactions on the Meeting of Employer Obligations).
} 
solutions from beginning to end of the compliance process. A critical element of the approach is to target taxpayers with outstanding obligations with the right intervention at the right time. Motivated by this approach, the intervention replaces internal guidelines of the ATO business line "Employer Obligations" by guidelines of another business line ("Indirect Tax") to raise awareness of the relevance of tax debt payments. The guideline documents are too long to be presented here. They are included in the analysis plan of the trial.

The second part of the trial focuses on desk audits. Desk auditors may contact businesses when they detect outstanding employer obligations and send a "notice of audit" as followup letter. Two changes were made to this procedure: First, the phone script of auditors of the treatment group was modified to offer taxpayers a direct connection ("warm transfer") to an ATO officer to work out a suitable payment plan. Offering a warm transfer during phone conversations is consistent with the Payment Thinking approach, which emphasizes the importance of the timing of interventions. The offer may also increase the taxpayer's perception of being treated fairly and respectfully by the tax authority, which in turn may improve compliance (Wenzel, 2006; Gangl et al., 2013). Second, the follow-up letter was simplified. In contrast to the control letter, which consists of five tightly written pages, the treatment letter summarizes the most important issues on the first page and presents further information in an appendix. Recent research in the UK has linked the simplification of letters and official documents to improvements in outcomes, including compliance behavior (Behavioural Insights Team, 2015, 2016).

\subsection{Empirical Strategy and Data}

To ascertain the effects of the two parts of the trial, we estimate separate regressions for our samples of field and desk auditors. Auditors of both groups were randomly assigned to treatment and control groups and each auditor worked on several (typically 5-6) cases. To account for the inclusion of cases that were treated by the same auditor, we report standard errors that were clustered at the auditor level. ${ }^{14}$ Our analysis is based on treatment and control

\footnotetext{
${ }^{14} \mathrm{~A}$ potential problem of the trial design is the possibility of systematic assignment of auditors to their cases. For example, our results would be biased if more experienced auditors would have been assigned to more difficult cases. In order to examine this possibility, we asked all auditors to take part in a small survey to provide information about their gender, level of education and the number of years of auditor experience. Unfortunately, we only received responses from 24 auditors (16 field and eight desk auditors). However, when studying the relationship between auditor characteristics and variables that are expected to be associated with the difficulty of a case (including the amount owed at the start of the case, the income of the firm and the
} 
comparisons of the cases that field and desk auditors completed during the study period. Our general strategy for studying the effect of a treatment on an outcome measure of interest is to estimate the model

$$
Y_{i}^{d}=\delta_{0}^{d}+\delta_{1}^{d} T_{i}^{d}+\nu_{i}^{d}, \quad i=\underbrace{1,2, \ldots, N_{0}^{d}}_{\text {treatment group } 1}, \underbrace{N_{0}^{d}+1, \ldots, N_{0}^{d}+N_{1}^{d}}_{\text {control group 1 }}, \quad d=0,1,
$$

where $d$ is an indicator variable that takes on the value 1 if a case belongs to a desk auditor, and 0 otherwise. $T_{i}^{d}$ is the treatment indicator and $\nu_{i}^{d}$ is the model error term. $\delta_{1}^{d}$ denotes the (unconditional) average treatment effect. We consider the following outcome measures: (i) the amount collected during the audit, (ii) the amount owed by the taxpayer after the case is closed, (iii) a variable indicating whether the ATO lodged an overdue default assessment (reflecting that taxpayers did not comply with their filing obligations), and (iv) the number of days of the case cycle.

We also estimate separate models for field and desk auditors including a set of control variables:

$$
Y_{i}^{d}=\lambda_{0}^{d}+\lambda_{1}^{d} T_{i}^{d}+Z_{i}^{d} \lambda_{2}^{d}+\omega_{i}^{d}, \quad i=1,2, \ldots, N_{0}^{d}+N_{1}^{d}, \quad d=0,1,
$$

where $Z_{i}^{d}$ denotes the set of control variables and $\omega_{i}$ is the error term. The parameter $\lambda_{1}^{d}$ is the (conditional) average treatment effect after controlling for $Z_{i}^{d}$. Appendix $\mathrm{C}$ includes a list of the potential control variables provided by the ATO. Table 5 shows the baseline characteristics of the treatment and control groups for both field and desk auditors. The $p$-values in Table 5 reveal that differences in characteristics between treatment and control group are largely insignificant, with the exception of three cases: differences in the share of arts and recreation services in the sample of cases handled by field auditors, differences in the share of accommodation and food services as well as in the share of professional, scientific and technical services in the sample of cases handled by desk auditors. Consequently, we include industry indicators as control variables in our conditional model.

[Table 5 about here.]

We use a linear regression model to estimate equations (3) and (4). Moreover, we examine the consequences of using binary Probit models to estimate the marginal effects of the number of employees), we find no evidence of systematic assignment. 
treatment indicators on the outcome variable indicating whether the ATO lodged an overdue default assessment. Finally, we estimate a Poisson regression model to study the effect of the treatments on the number of days of the case cycle.

\subsection{Results}

The findings presented in Table 6 suggest that changing internal guidelines used by field auditors (Treatment 1) leads to a significant decline in the amount owed by the taxpayer at the end of the case. The unconditional model indicates that the amount owed by the taxpayer at the end of the case is about $\$ 69,000$ lower for members of the treatment group than for members of the control group ( $p$-value: 0.05 ). However, this effect drops to about $\$ 44,000$ and is no longer significant ( $p$-value: 0.16$)$ when we control for group differences in industries. More importantly, we find that the treatment did not lead to an increase in tax revenues because the amount collected during the audit did not change significantly. ${ }^{15}$

[Table 6 about here.]

The estimates associated with the desk audit (Treatment 2) reveal that the proportion of default assessments raised by the ATO during the audit declined significantly, an indication that more businesses complied with their filing obligation. The observed difference between treatment and control group is only based on 94 observations but it is statistically significant (at a $5 \%$ level) and the 20.7 percentage point gap is substantial, indicating that simplifying the letter and changing the phone script led to a considerable decline in default assessments. (Default assessments were raised in $30 \%$ of the cases of the control group, whereas the corresponding proportion of the treatment group is only 9.3\%.) We obtain an even larger and more significant estimate of the difference when we include control variables in our model.

Taken together, our results demonstrate that the provision of assistance in phone conversations and the simplification of a follow-up letter led to a decline in the proportion of default assessments, suggesting that businesses are responsive to certain nudges. It is important to note that the small sample size is a major limitation of the study and we only observe significant effects because the observed differences between treatment and control group are considerable.

\footnotetext{
${ }^{15}$ Changes in the amount owed at the end of the case are not necessarily in line with changes in the amount collected because taxpayers can accrue additional debt during the case cycle.
} 


\section{Conclusion and Discussion}

This paper presents the results obtained from two Randomized Controlled Trials (RCTs) that were conducted in collaboration with the Australian Taxation Office (ATO). The first trial was designed to test the effect of four non-deterrence interventions (modified versions of a letter that the ATO sends to businesses if their reported transactions vary considerably from normal business activity) on response rates, the timing of payments and the amount of payments of liabilities. Our empirical findings reveal that the four treatments did not have a significant effect on any of the outcome measures considered in our analysis. Although small treatments and small sample sizes may be responsible for this result, it is also possible that businesses are simply not very responsive to this type of intervention.

The aim of the second trial was to improve internal procedures and engagement strategies with taxpayers. The trial consists of two parts. The first part assesses the effect of changing internal guidelines used by field auditors to raise awareness of the relevance of tax debt payments. The second part focuses on studying the effect of changing the script that desk auditors use for phone conversations and simplifying a follow-up letter to businesses. Outcome measures include debt collection measures, the duration of case cycles, and a variable indicating whether a default assessment was raised by the ATO during the audit (which happens when businesses do not comply with their filing obligations).

We find that changing the guidelines of field auditors reduced the amount owed by the average taxpayer at the end of the case cycle by about $\$ 69,000$. However, this effect is no longer significant when we add relevant control variables to our model. At the same time, the amount collected during the audit did not increase significantly, suggesting that the treatment did not lead to an increase in tax revenues. In contrast, changing the phone script of desk auditors to facilitate the establishment of payment arrangements and simplifying the follow-up letter reduced the proportion of default assessments raised from $30 \%$ to $9.3 \%$. The observed difference between treatment and control group is only based on 94 observations but the observed gap is statistically significant and robust with regard to the inclusion of relevant control variables.

What can we learn from the results of the two trials? First, from a policy perspective, our results suggest that clearly noticeable interventions are required when targeting businesses to induce behavioral change. While small changes to letters have been found to result in behav- 
ioral changes among individual taxpayers, our results provide first tentative evidence indicating that businesses are less responsive to low-key nudges, and potentially that improvements to correspondence that has already been made means that the marginal benefits of further tweaks are diminishing. This result is consistent with the findings of Ariel (2012), the only previous study that uses moral persuasion messages to target business tax compliance.

Second, our findings point to the most promising domains to improve voluntary business tax compliance. Businesses appear to act "more rationally" than individuals due to structural factors (businesses may have more than one person who is responsible for tax filing and less likely to be affected by the decision than individual taxpayers). Consequently, interventions that aim to reduce friction costs for businesses appear to be most promising when targeting compliance behavior. Our second trial shows that changing the phone script of desk auditors to help setting up a payment arrangement and simplifying the follow-up letter has a substantial effect on the filing behavior of businesses. Therefore, our recommendation to tax authorities is to identify areas in which barriers may prevent businesses from compliant behavior, and to apply behavioral insights in these areas.

Finally, more systematic business tax compliance research is needed. Not understanding the broader implications of business tax non-compliance is associated with severe societal and administrative costs (Ariel, 2012). We therefore welcome that tax administrators are increasingly open to running RCTs to evaluate the effects of policy changes on the real-world behavior of taxpayers. This development should be supported by governments and institutional representatives alike to derive a sound base of empirical insights into the effectiveness of different approaches to increase voluntary tax compliance. 


\section{Tables and Figures}

Table 1: Baseline Characteristics - Trial I

\begin{tabular}{|c|c|c|c|c|c|c|c|c|c|c|c|c|c|c|}
\hline & \multicolumn{2}{|c|}{ Control } & \multicolumn{2}{|c|}{ Treatment 1} & \multirow[b]{2}{*}{$p$-value } & \multicolumn{2}{|c|}{ Treatment 2} & \multirow[b]{2}{*}{$p$-value } & \multicolumn{2}{|c|}{ Treatment 3} & \multirow[b]{2}{*}{$p$-value } & \multicolumn{2}{|c|}{ Treatment 4} & \multirow[b]{2}{*}{$p$-value } \\
\hline & Mean & $N$ & Mean & $N$ & & Mean & $N$ & & Mean & $N$ & & Mean & $N$ & \\
\hline \multicolumn{15}{|l|}{ 2014/15: Number of } \\
\hline BAS lodged & 6.667 & 589 & 6.419 & 585 & 0.299 & 6.796 & 589 & 0.595 & 6.835 & 588 & 0.491 & 6.588 & 587 & 0.743 \\
\hline BAS with net GST payable & 2.114 & 589 & 2.144 & 585 & 0.846 & 2.190 & 589 & 0.635 & 2.233 & 588 & 0.453 & 2.215 & 587 & 0.521 \\
\hline GST refunds lodged & 4.553 & 589 & 4.275 & 585 & 0.252 & 4.606 & 589 & 0.831 & 4.602 & 588 & 0.845 & 4.373 & 587 & 0.456 \\
\hline BAS with amount payable & 2.314 & 547 & 2.407 & 541 & 0.592 & 2.456 & 542 & 0.424 & 2.631 & 550 & 0.077 & 2.574 & 542 & 0.143 \\
\hline BAS with net refund & 4.256 & 589 & 3.986 & 585 & 0.246 & 4.297 & 589 & 0.865 & 4.230 & 588 & 0.912 & 4.000 & 587 & 0.275 \\
\hline \multicolumn{15}{|l|}{ 2014/15: Total net amount } \\
\hline GST payable & 193,602 & 589 & 150,074 & 585 & 0.256 & 158,854 & 589 & 0.364 & 136,893 & 588 & 0.129 & 136,665 & 587 & 0.139 \\
\hline GST refundable & $-524,315$ & 589 & $-386,481$ & 585 & 0.137 & $-466,218$ & 589 & 0.561 & $-431,213$ & 588 & 0.325 & $-453,119$ & 587 & 0.470 \\
\hline Payable & 251,480 & 589 & 205,994 & 585 & 0.330 & 219,379 & 589 & 0.504 & 206,486 & 588 & 0.349 & 239,210 & 587 & 0.851 \\
\hline Refundable & $-455,156$ & 589 & $-323,012$ & 585 & 0.074 & $-411,054$ & 589 & 0.605 & $-375,798$ & 588 & 0.310 & $-389,392$ & 587 & 0.428 \\
\hline High risk score & 0.355 & 589 & 0.354 & 585 & 0.972 & 0.355 & 589 & 1.000 & 0.354 & 588 & 0.969 & 0.358 & 587 & 0.917 \\
\hline Accounting method: Cash & 0.416 & 589 & 0.402 & 584 & 0.637 & 0.413 & 589 & 0.906 & 0.427 & 588 & 0.705 & 0.413 & 586 & 0.917 \\
\hline Lodgement tax period ${ }^{\dagger}$ & 80.1 & 589 & 82.2 & 585 & 0.536 & 84.3 & 589 & 0.251 & 85.2 & 588 & 0.169 & 80.7 & 587 & 0.837 \\
\hline Days between lodgements & 40.4 & 589 & 41.3 & 585 & 0.546 & 38.5 & 589 & 0.241 & 38.1 & 588 & 0.157 & 39.5 & 587 & 0.571 \\
\hline \multicolumn{15}{|l|}{ Lodgement method } \\
\hline Business Portal & 0.309 & 589 & 0.244 & 585 & 0.013 & 0.284 & 589 & 0.339 & 0.264 & 588 & 0.085 & 0.281 & 587 & 0.294 \\
\hline Corporate Data Capture & 0.122 & 589 & 0.130 & 585 & 0.692 & 0.143 & 589 & 0.303 & 0.155 & 588 & 0.106 & 0.106 & 587 & 0.370 \\
\hline ELS & 0.311 & 589 & 0.344 & 585 & 0.230 & 0.321 & 589 & 0.707 & 0.327 & 588 & 0.560 & 0.349 & 587 & 0.160 \\
\hline Electronic Service Delivery & 0.059 & 589 & 0.036 & 585 & 0.058 & 0.053 & 589 & 0.613 & 0.034 & 588 & 0.039 & 0.041 & 587 & 0.145 \\
\hline Tax Agent Portal & 0.144 & 589 & 0.186 & 585 & 0.052 & 0.148 & 589 & 0.869 & 0.160 & 588 & 0.458 & 0.179 & 587 & 0.107 \\
\hline Other & 0.054 & 589 & 0.060 & 585 & 0.685 & 0.053 & 589 & 0.897 & 0.061 & 588 & 0.612 & 0.044 & 587 & 0.427 \\
\hline \multicolumn{15}{|l|}{ Lodgement cycle GST } \\
\hline Annually & 0.031 & 589 & 0.038 & 585 & 0.506 & 0.053 & 589 & 0.058 & 0.053 & 588 & 0.057 & 0.031 & 587 & 0.992 \\
\hline Monthly & 0.304 & 589 & 0.297 & 585 & 0.809 & 0.328 & 589 & 0.380 & 0.320 & 588 & 0.558 & 0.298 & 587 & 0.829 \\
\hline Quarterly & 0.666 & 589 & 0.665 & 585 & 0.983 & 0.620 & 589 & 0.101 & 0.628 & 588 & 0.173 & 0.671 & 587 & 0.836 \\
\hline
\end{tabular}

Continued on next page... 
Table 1 (Continued)

\begin{tabular}{|c|c|c|c|c|c|c|c|c|c|c|c|c|c|c|}
\hline & \multicolumn{2}{|c|}{ Control } & \multicolumn{2}{|c|}{ Treatment 1} & \multirow[b]{2}{*}{$p$-value } & \multicolumn{2}{|c|}{ Treatment 2} & \multirow[b]{2}{*}{$p$-value } & \multicolumn{2}{|c|}{ Treatment 3} & \multirow[b]{2}{*}{$p$-value } & \multicolumn{2}{|c|}{ Treatment 4} & \multirow[b]{2}{*}{$p$-value } \\
\hline & Mean & $N$ & Mean & $N$ & & Mean & $N$ & & Mean & $N$ & & Mean & $N$ & \\
\hline \multicolumn{15}{|l|}{ Market segment } \\
\hline Micro enterprise & 0.428 & 589 & 0.474 & 585 & 0.116 & 0.448 & 589 & 0.481 & 0.451 & 588 & 0.430 & 0.475 & 587 & 0.102 \\
\hline Not for profit enterprise & 0.085 & 589 & 0.085 & 585 & 0.972 & 0.073 & 589 & 0.450 & 0.082 & 588 & 0.840 & 0.092 & 587 & 0.668 \\
\hline Small/Medium enterprise & 0.484 & 589 & 0.441 & 585 & 0.141 & 0.475 & 589 & 0.771 & 0.463 & 588 & 0.465 & 0.428 & 587 & 0.053 \\
\hline Other & 0.003 & 589 & 0.000 & 585 & 0.158 & 0.003 & 589 & 1.000 & 0.005 & 588 & 0.653 & 0.005 & 587 & 0.652 \\
\hline \multicolumn{15}{|l|}{ Client type } \\
\hline Company & 0.457 & 589 & 0.463 & 585 & 0.822 & 0.501 & 589 & 0.129 & 0.476 & 588 & 0.503 & 0.523 & 587 & 0.023 \\
\hline Individual & 0.049 & 589 & 0.050 & 585 & 0.979 & 0.054 & 589 & 0.693 & 0.037 & 588 & 0.319 & 0.051 & 587 & 0.883 \\
\hline Partnership & 0.132 & 589 & 0.154 & 585 & 0.295 & 0.124 & 589 & 0.663 & 0.139 & 588 & 0.725 & 0.135 & 587 & 0.914 \\
\hline Superannuation fund & 0.024 & 589 & 0.024 & 585 & 0.985 & 0.017 & 589 & 0.410 & 0.037 & 588 & 0.174 & 0.026 & 587 & 0.844 \\
\hline Trust & 0.338 & 589 & 0.309 & 585 & 0.298 & 0.304 & 589 & 0.212 & 0.310 & 588 & 0.299 & 0.266 & 587 & 0.007 \\
\hline \multicolumn{15}{|l|}{ State } \\
\hline Australian Capital Territory & 0.024 & 589 & 0.014 & 585 & 0.202 & 0.007 & 589 & 0.017 & 0.010 & 588 & 0.072 & 0.009 & 587 & 0.038 \\
\hline New South Wales & 0.260 & 589 & 0.251 & 585 & 0.739 & 0.263 & 589 & 0.895 & 0.270 & 588 & 0.679 & 0.293 & 587 & 0.202 \\
\hline Northern Territory & 0.002 & 589 & 0.007 & 585 & 0.176 & 0.007 & 589 & 0.179 & 0.009 & 588 & 0.101 & 0.012 & 587 & 0.033 \\
\hline Queensland & 0.178 & 589 & 0.156 & 585 & 0.297 & 0.204 & 589 & 0.266 & 0.190 & 588 & 0.589 & 0.124 & 587 & 0.010 \\
\hline South Australia & 0.049 & 589 & 0.065 & 585 & 0.246 & 0.058 & 589 & 0.518 & 0.058 & 588 & 0.513 & 0.077 & 587 & 0.053 \\
\hline Tasmania & 0.019 & 589 & 0.012 & 585 & 0.350 & 0.017 & 589 & 0.826 & 0.010 & 588 & 0.223 & 0.012 & 587 & 0.346 \\
\hline Victoria & 0.258 & 589 & 0.280 & 585 & 0.390 & 0.284 & 589 & 0.326 & 0.267 & 588 & 0.728 & 0.273 & 587 & 0.573 \\
\hline Western Australia & 0.139 & 589 & 0.149 & 585 & 0.643 & 0.107 & 589 & 0.092 & 0.129 & 588 & 0.616 & 0.136 & 587 & 0.884 \\
\hline \multicolumn{15}{|l|}{ Industry } \\
\hline Services & 0.306 & 589 & 0.349 & 585 & 0.115 & 0.324 & 589 & 0.490 & 0.340 & 588 & 0.205 & 0.344 & 587 & 0.158 \\
\hline Agricultural & 0.188 & 589 & 0.173 & 585 & 0.482 & 0.165 & 589 & 0.285 & 0.131 & 588 & 0.007 & 0.167 & 587 & 0.335 \\
\hline Construction & 0.170 & 589 & 0.157 & 585 & 0.562 & 0.166 & 589 & 0.876 & 0.162 & 588 & 0.705 & 0.196 & 587 & 0.246 \\
\hline Transport, comms, utilities & 0.046 & 589 & 0.048 & 585 & 0.870 & 0.039 & 589 & 0.563 & 0.036 & 588 & 0.380 & 0.036 & 587 & 0.383 \\
\hline Financial, insurance & 0.107 & 589 & 0.084 & 585 & 0.176 & 0.104 & 589 & 0.850 & 0.112 & 588 & 0.772 & 0.082 & 587 & 0.140 \\
\hline Manufacturing & 0.044 & 589 & 0.038 & 585 & 0.572 & 0.053 & 589 & 0.497 & 0.043 & 588 & 0.891 & 0.048 & 587 & 0.771 \\
\hline Mining & 0.005 & 589 & 0.014 & 585 & 0.127 & 0.007 & 589 & 0.705 & 0.015 & 588 & 0.081 & 0.010 & 587 & 0.313 \\
\hline Retail and wholesale trade & 0.119 & 589 & 0.133 & 585 & 0.455 & 0.134 & 589 & 0.430 & 0.156 & 588 & 0.061 & 0.114 & 587 & 0.802 \\
\hline Other & 0.015 & 589 & 0.005 & 585 & 0.084 & 0.008 & 589 & 0.282 & 0.005 & 588 & 0.082 & 0.003 & 587 & 0.034 \\
\hline
\end{tabular}


TAble 1 (Continued)

\begin{tabular}{|c|c|c|c|c|c|c|c|c|c|c|c|c|c|c|}
\hline & \multicolumn{2}{|c|}{ Control } & \multicolumn{2}{|c|}{ Treatment 1} & \multirow[b]{2}{*}{$p$-value } & \multicolumn{2}{|c|}{ Treatment 2} & \multirow[b]{2}{*}{$p$-value } & \multicolumn{2}{|c|}{ Treatment 3} & \multirow[b]{2}{*}{$p$-value } & \multicolumn{2}{|c|}{ Treatment 4} & \multirow[b]{2}{*}{$p$-value } \\
\hline & Mean & $N$ & Mean & $N$ & & Mean & $N$ & & Mean & $N$ & & Mean & $N$ & \\
\hline \multicolumn{15}{|c|}{$\begin{array}{l}\text { Income tax } \\
\text { return lodged }\end{array}$} \\
\hline 2011-12 & 0.596 & 589 & 0.583 & 585 & 0.651 & 0.587 & 589 & 0.767 & 0.614 & 588 & 0.527 & 0.579 & 587 & 0.561 \\
\hline $2012-13$ & 0.650 & 589 & 0.615 & 585 & 0.215 & 0.620 & 589 & 0.276 & 0.662 & 588 & 0.683 & 0.608 & 587 & 0.135 \\
\hline 2013-14 & 0.694 & 589 & 0.665 & 585 & 0.280 & 0.659 & 589 & 0.191 & 0.704 & 588 & 0.717 & 0.658 & 587 & 0.177 \\
\hline 2014-15 & 0.742 & 589 & 0.692 & 585 & 0.059 & 0.705 & 589 & 0.152 & 0.726 & 588 & 0.541 & 0.731 & 587 & 0.666 \\
\hline 2011-12 & $8,848,597$ & 351 & $8,661,203$ & 341 & 0.912 & $12,460,393$ & 346 & 0.244 & $8,522,519$ & 361 & 0.825 & $8,597,107$ & 340 & 0.873 \\
\hline 2012-13 & $8,443,833$ & 383 & $8,558,430$ & 360 & 0.938 & $11,364,095$ & 365 & 0.107 & $8,400,651$ & 389 & 0.975 & $8,845,209$ & 357 & 0.794 \\
\hline 2013-14 & $10,448,734$ & 409 & $7,883,035$ & 389 & 0.326 & $11,573,349$ & 388 & 0.704 & $8,451,914$ & 414 & 0.431 & $8,630,701$ & 386 & 0.495 \\
\hline $2014-15$ & $8,877,988$ & 437 & $8,295,525$ & 405 & 0.688 & $10,187,145$ & 415 & 0.427 & $8,418,841$ & 427 & 0.747 & $8,136,783$ & 429 & 0.602 \\
\hline 2015-16 & $12,517,915$ & 48 & $12,110,402$ & 46 & 0.950 & $10,693,910$ & 49 & 0.776 & $16,119,142$ & 46 & 0.616 & $4,797,563$ & 49 & 0.128 \\
\hline \multicolumn{15}{|c|}{$\begin{array}{l}\text { Total business } \\
\text { expenses }\end{array}$} \\
\hline $2014-15$ & $8,232,163$ & 437 & $8,231,392$ & 405 & 1.000 & $12,058,769$ & 415 & 0.174 & $8,593,934$ & 427 & 0.794 & $7,683,273$ & 429 & 0.688 \\
\hline 2015-16 & $13,003,543$ & 48 & $10,809,845$ & 46 & 0.732 & $14,792,311$ & 49 & 0.820 & $18,451,685$ & 46 & 0.464 & $4,438,102$ & 49 & 0.099 \\
\hline \multicolumn{15}{|c|}{ Total profit/loss } \\
\hline 2011-12 & 497,325 & 351 & $-45,524$ & 341 & 0.218 & 694,536 & 346 & 0.623 & $-214,048$ & 361 & 0.092 & 482,927 & 340 & 0.943 \\
\hline 2012-13 & 395,839 & 383 & 532,680 & 360 & 0.688 & $1,099,655$ & 365 & 0.081 & 65,402 & 389 & 0.293 & 196,413 & 357 & 0.523 \\
\hline 2013-14 & $2,613,363$ & 409 & 100,607 & 389 & 0.251 & $1,024,685$ & 388 & 0.486 & $-64,728$ & 414 & 0.210 & 449,366 & 386 & 0.321 \\
\hline 2014-15 & 645,825 & 437 & 64,133 & 405 & 0.154 & $-1,871,624$ & 415 & 0.254 & $-175,093$ & 427 & 0.019 & 453,510 & 429 & 0.494 \\
\hline 2015-16 & $-485,628$ & 48 & $1,300,558$ & 46 & 0.087 & $-4,098,401$ & 49 & 0.373 & $-2,332,543$ & 46 & 0.205 & 359,460 & 49 & 0.335 \\
\hline
\end{tabular}

Note: $p$-values refer to the comparison of means between treatment and control groups.

$\dagger$ Days between the original BAS lodgement date and the last BAS lodgement date. 
Table 2: Treatment Effects (OLS) - Trial I

\begin{tabular}{|c|c|c|c|c|}
\hline & Treatment 1 & Treatment 2 & Treatment 3 & Treatment 4 \\
\hline $\begin{array}{l}\text { Total amount of payments by the taxpayer } \\
\text { after } 12 / 11 / 2015\end{array}$ & $\begin{array}{c}-69,483 \\
(72,864) \\
{[450]}\end{array}$ & $\begin{array}{c}13,336 \\
(79,522) \\
{[455]}\end{array}$ & $\begin{array}{c}-59,053 \\
(71,730) \\
{[456]}\end{array}$ & $\begin{array}{c}-59,440 \\
(77,433) \\
{[446]}\end{array}$ \\
\hline Net amount of GST: original minus revised BAS & $\begin{array}{c}31,103 \\
(37,432) \\
{[86]}\end{array}$ & $\begin{array}{c}19,385 \\
(40,769) \\
{[89]}\end{array}$ & $\begin{array}{c}28,188 \\
(41,271) \\
{[80]}\end{array}$ & $\begin{array}{c}-33,396 \\
(59,911) \\
{[87]}\end{array}$ \\
\hline Revised net amount of all taxation items on BAS & $\begin{array}{c}18,876 \\
(35,131) \\
{[86]}\end{array}$ & $\begin{array}{c}3,148 \\
(38,914) \\
{[89]}\end{array}$ & $\begin{array}{c}17,972 \\
(38,079) \\
{[80]}\end{array}$ & $\begin{array}{c}-47,204 \\
(58,900) \\
{[87]}\end{array}$ \\
\hline Revision was lodged by taxpayer & $\begin{array}{c}0.004 \\
(0.015) \\
{[1174]}\end{array}$ & $\begin{array}{c}0.008 \\
(0.015) \\
{[1178]}\end{array}$ & $\begin{array}{c}-0.007 \\
(0.015) \\
{[1177]}\end{array}$ & $\begin{array}{c}0.005 \\
(0.015) \\
{[1176]}\end{array}$ \\
\hline GST revision in favor of ATO & $\begin{array}{c}-0.039 \\
(0.103) \\
{[86]}\end{array}$ & $\begin{array}{c}0.132 \\
(0.105) \\
{[89]}\end{array}$ & $\begin{array}{c}0.117 \\
(0.111) \\
{[80]}\end{array}$ & $\begin{array}{c}-0.046 \\
(0.102) \\
{[87]}\end{array}$ \\
\hline GST revision in favor of client & $\begin{array}{c}0.012 \\
(0.094) \\
{[86]}\end{array}$ & $\begin{array}{c}-0.068 \\
(0.086) \\
{[89]}\end{array}$ & $\begin{array}{c}-0.054 \\
(0.093) \\
{[80]}\end{array}$ & $\begin{array}{c}0.051 \\
(0.096) \\
{[87]}\end{array}$ \\
\hline No change after GST revision & $\begin{array}{c}0.027 \\
(0.108) \\
{[86]}\end{array}$ & $\begin{array}{c}-0.064 \\
(0.104) \\
{[89]}\end{array}$ & $\begin{array}{c}-0.063 \\
(0.110) \\
{[80]}\end{array}$ & $\begin{array}{c}-0.005 \\
(0.106) \\
{[87]}\end{array}$ \\
\hline Revision of all taxable items in favor of ATO & $\begin{array}{c}-0.018 \\
(0.107) \\
{[86]}\end{array}$ & $\begin{array}{c}0.148 \\
(0.106) \\
{[89]}\end{array}$ & $\begin{array}{c}0.095 \\
(0.112) \\
{[80]}\end{array}$ & $\begin{array}{c}-0.049 \\
(0.105) \\
{[87]}\end{array}$ \\
\hline Revision of all taxable items in favor of client & $\begin{array}{c}0.011 \\
(0.097) \\
{[86]}\end{array}$ & $\begin{array}{c}-0.028 \\
(0.093) \\
{[89]}\end{array}$ & $\begin{array}{c}0.001 \\
(0.100) \\
{[80]}\end{array}$ & $\begin{array}{c}0.094 \\
(0.100) \\
{[87]}\end{array}$ \\
\hline $\begin{array}{l}\text { No change after revision in amount of all } \\
\text { taxable items }\end{array}$ & $\begin{array}{c}0.008 \\
(0.103) \\
{[86]}\end{array}$ & $\begin{array}{c}-0.121 \\
(0.094) \\
{[89]}\end{array}$ & $\begin{array}{c}-0.096 \\
(0.102) \\
{[80]}\end{array}$ & $\begin{array}{c}-0.044 \\
(0.100) \\
{[87]}\end{array}$ \\
\hline $\begin{array}{l}\text { Number of payments by taxpayer after } \\
12 / 11 / 2015\end{array}$ & $\begin{array}{c}0.104 \\
(0.159) \\
{[1174]}\end{array}$ & $\begin{array}{c}0.307 \\
(0.170) \\
{[1178]}\end{array}$ & $\begin{array}{c}0.101 \\
(0.155) \\
{[1177]}\end{array}$ & $\begin{array}{c}0.047 \\
(0.161) \\
{[1176]}\end{array}$ \\
\hline $\begin{array}{l}\text { Number of days until first payment by the } \\
\text { taxpayer after } 12 / 11 / 2015\end{array}$ & $\begin{array}{c}0.128 \\
(1.474) \\
{[450]}\end{array}$ & $\begin{array}{c}-0.054 \\
(1.439) \\
{[455]}\end{array}$ & $\begin{array}{c}1.684 \\
(1.511) \\
{[456]}\end{array}$ & $\begin{array}{c}0.920 \\
(1.445) \\
{[446]}\end{array}$ \\
\hline
\end{tabular}

Note: Coefficients obtained from a linear regression model without control variables. Standard errors in parentheses. Number of observations in brackets. 
Table 3: Treatment Effects, Binary Outcome Variables (Probit) - Trial I

\begin{tabular}{ccccc}
\hline & Treatment 1 & Treatment 2 & Treatment 3 & Treatment 4 \\
\hline Revision was lodged by taxpayer & 0.004 & 0.007 & -0.005 & 0.001 \\
& $(0.015)$ & $(0.016)$ & $(0.015)$ & $(0.016)$ \\
& {$[1174]$} & {$[1160]$} & {$[1177]$} & {$[1147]$} \\
GST revision in favor of ATO & -0.046 & 0.131 & 0.109 & -0.034 \\
& $(0.103)$ & $(0.101)$ & $(0.108)$ & $(0.102)$ \\
& {$[86]$} & {$[89]$} & {$[80]$} & {$[86]$} \\
GST revision in favor of client & 0.015 & -0.067 & -0.067 & 0.058 \\
& $(0.094)$ & $(0.084)$ & $(0.095)$ & $(0.095)$ \\
No change after GST revision & {$[86]$} & {$[89]$} & {$[76]$} & {$[86]$} \\
& 0.030 & -0.064 & -0.046 & -0.029 \\
Revision of all taxable items in & $(0.107)$ & $(0.102)$ & $(0.107)$ & $(0.105)$ \\
favor of ATO & {$[86]$} & {$[89]$} & {$[80]$} & {$[86]$} \\
Revision of all taxable items in & -0.027 & 0.147 & 0.087 & -0.035 \\
favor of client & {$[0.106)$} & $(0.101)$ & $(0.110)$ & $(0.105)$ \\
& 0.026 & -0.028 & -0.012 & {$[86]$} \\
No change after revision in & {$[0.096)$} & $(0.091)$ & $(0.102)$ & $(0.099$ \\
amount of all taxable items & {$[86]$} & {$[89]$} & {$[76]$} & {$[86]$} \\
& 0.002 & -0.119 & -0.083 & -0.067 \\
& {$[0.103)$} & $(0.091)$ & $(0.097)$ & $(0.099)$ \\
& {$[86]$} & {$[89]$} & {$[80]$} & {$[86]$}
\end{tabular}

Note: Marginal effects obtained from a binary probit model including control variables. Standard errors in parentheses. Number of observations in brackets.

Table 4: Treatment Effects, Count Data (Poisson Regression) - Trial I

\begin{tabular}{ccccc}
\hline & Treatment 1 & Treatment 2 & Treatment 3 & Treatment 4 \\
\hline Number of payments by taxpayer & 0.202 & 0.315 & 0.113 & -0.045 \\
after $12 / 11 / 2015$ & $(0.160)$ & $(0.172)$ & $(0.150)$ & $(0.156)$ \\
& {$[1174]$} & {$[1178]$} & {$[1177]$} & {$[1176]$} \\
Number of days until first payment & 0.052 & -0.112 & 1.530 & 1.096 \\
by taxpayer after 12/11/2015 & $(1.466)$ & $(1.440)$ & $(1.538)$ & $(1.467)$ \\
& {$[450]$} & {$[455]$} & {$[456]$} & {$[446]$} \\
\hline
\end{tabular}

Note: Marginal effects obtained from Poisson regression model including control variables. Robust standard errors in parentheses. Number of observations in brackets. 
Table 5: Baseline Characteristics - Trial II

\begin{tabular}{|c|c|c|c|c|c|c|c|c|c|c|}
\hline & \multicolumn{2}{|c|}{ Control 1} & \multicolumn{2}{|c|}{ Treatment 1} & \multirow[b]{2}{*}{$p$-value } & \multicolumn{2}{|c|}{ Control 2} & \multicolumn{2}{|c|}{ Treatment 2} & \multirow[b]{2}{*}{$p$-value } \\
\hline & Mean & $N$ & Mean & $N$ & & Mean & $N$ & Mean & $N$ & \\
\hline Amount owed at start & 63,891 & 81 & 39,014 & 115 & 0.154 & 32,287 & 37 & 22,767 & 47 & 0.299 \\
\hline Number of employees & 10.7 & 89 & 23.0 & 122 & 0.440 & 8.5 & 39 & 5.2 & 54 & 0.125 \\
\hline Total business income & 608,320 & 68 & 592,904 & 94 & 0.946 & 669,165 & 28 & 493,580 & 38 & 0.665 \\
\hline \multicolumn{11}{|l|}{ Market segment } \\
\hline Not for profit enterprise & 0.022 & 90 & 0.024 & 125 & 0.932 & 0.000 & 40 & 0.019 & 54 & 0.390 \\
\hline Micro enterprise & 0.856 & 90 & 0.912 & 125 & 0.195 & 0.925 & 40 & 0.889 & 54 & 0.560 \\
\hline Small/medium enterprise & 0.100 & 90 & 0.064 & 125 & 0.336 & 0.075 & 40 & 0.093 & 54 & 0.765 \\
\hline Large market enterprise & 0.022 & 90 & 0.000 & 125 & 0.093 & 0.000 & 40 & 0.000 & 54 & 1.000 \\
\hline \multicolumn{11}{|l|}{ Industry } \\
\hline Agriculture, Forestry and Fishing & 0.056 & 90 & 0.024 & 125 & 0.228 & 0.075 & 40 & 0.093 & 54 & 0.765 \\
\hline Mining & 0.011 & 90 & 0.000 & 125 & 0.238 & 0.000 & 40 & 0.000 & 54 & 1.000 \\
\hline Manufacturing & 0.067 & 90 & 0.064 & 125 & 0.938 & 0.025 & 40 & 0.037 & 54 & 0.745 \\
\hline Construction & 0.178 & 90 & 0.208 & 125 & 0.583 & 0.175 & 40 & 0.093 & 54 & 0.238 \\
\hline Wholesale Trade & 0.056 & 90 & 0.040 & 125 & 0.595 & 0.000 & 40 & 0.037 & 54 & 0.220 \\
\hline Retail Trade & 0.044 & 90 & 0.056 & 125 & 0.706 & 0.150 & 40 & 0.167 & 54 & 0.829 \\
\hline Accomodation and Food Services & 0.111 & 90 & 0.152 & 125 & 0.388 & 0.075 & 40 & 0.241 & 54 & 0.032 \\
\hline Transport, Postal and Warehousing & 0.111 & 90 & 0.056 & 125 & 0.139 & 0.075 & 40 & 0.130 & 54 & 0.399 \\
\hline Information Media and Telecommunications & 0.022 & 90 & 0.000 & 125 & 0.093 & 0.000 & 40 & 0.000 & 54 & 1.000 \\
\hline Financial and Insurance Services & 0.022 & 90 & 0.032 & 125 & 0.669 & 0.025 & 40 & 0.019 & 54 & 0.831 \\
\hline Rental Hiring and Real Estate Services & 0.022 & 90 & 0.016 & 125 & 0.740 & 0.025 & 40 & 0.037 & 54 & 0.745 \\
\hline Professional, Scientific and Technical Services & 0.089 & 90 & & 125 & 0.370 & 0.175 & 40 & 0.000 & 54 & 0.001 \\
\hline Administrative and Support Services & 0.089 & 90 & 0.072 & 125 & 0.652 & 0.050 & 40 & 0.019 & 54 & 0.394 \\
\hline Public Administration and Safety & 0.000 & 90 & 0.008 & 125 & 0.396 & 0.000 & 40 & 0.019 & 54 & 0.390 \\
\hline Education and Training & 0.011 & 90 & 0.024 & 125 & 0.492 & 0.000 & 40 & 0.037 & 54 & 0.220 \\
\hline Health Care and Social Assistance & 0.022 & 90 & 0.024 & 125 & 0.932 & 0.050 & 40 & 0.000 & 54 & 0.095 \\
\hline Arts and Recreation Services & 0.033 & 90 & 0.000 & 125 & 0.039 & 0.000 & 40 & 0.000 & 54 & 1.000 \\
\hline Other Services & 0.056 & 90 & 0.096 & 125 & 0.279 & 0.100 & 40 & 0.074 & 54 & 0.659 \\
\hline
\end{tabular}

Note: $p$-values refer to the comparison of means between treatment and corresponding control group. 
Table 6: Treatment Effects - Trial II

\begin{tabular}{|c|c|c|c|c|}
\hline & \multicolumn{2}{|c|}{ Unconditional } & \multicolumn{2}{|c|}{ Conditional } \\
\hline & Treatment 1 & Treatment 2 & Treatment 1 & Treatment 2 \\
\hline \multicolumn{5}{|l|}{ OLS } \\
\hline Amount collected during the audit & $\begin{array}{c}-7,521 \\
(6,965) \\
{[215]}\end{array}$ & $\begin{array}{c}-13,327 \\
(13,807) \\
{[94]}\end{array}$ & $\begin{array}{c}-7,262 \\
(6,768) \\
{[215]}\end{array}$ & $\begin{array}{c}-9,887 \\
(11,749) \\
{[94]}\end{array}$ \\
\hline Amount owed by taxpayer after case is closed & $\begin{array}{c}-68,865^{*} \\
(33,202) \\
{[112]}\end{array}$ & $\begin{array}{c}-40,498 \\
(43,012) \\
{[56]}\end{array}$ & $\begin{array}{c}-43,915 \\
(29,734) \\
{[112]}\end{array}$ & $\begin{array}{c}-30,553 \\
(31,307) \\
{[56]}\end{array}$ \\
\hline ATO lodged overdue assessment & $\begin{array}{c}-0.046 \\
(0.036) \\
{[215]}\end{array}$ & $\begin{array}{c}-0.207^{*} \\
(0.087) \\
{[94]}\end{array}$ & $\begin{array}{c}-0.027 \\
(0.032) \\
{[215]}\end{array}$ & $\begin{array}{c}-0.225^{* *} \\
(0.074) \\
{[94]}\end{array}$ \\
\hline Days of the case cycle & $\begin{array}{c}2.388 \\
(10.293) \\
{[184]}\end{array}$ & $\begin{array}{c}5.332 \\
(8.383) \\
{[93]}\end{array}$ & $\begin{array}{c}2.335 \\
(10.045) \\
{[184]}\end{array}$ & $\begin{array}{c}5.456 \\
(7.840) \\
{[93]}\end{array}$ \\
\hline \multicolumn{5}{|l|}{ Probit (marginal effects) } \\
\hline ATO lodged overdue assessment & $\begin{array}{c}-0.044 \\
(0.034) \\
{[215]}\end{array}$ & $\begin{array}{c}-0.195^{*} \\
(0.075) \\
{[94]}\end{array}$ & $\begin{array}{c}-0.037 \\
(0.027) \\
{[177]}\end{array}$ & $\begin{array}{c}-0.187^{*} \\
(0.075) \\
{[94]}\end{array}$ \\
\hline \multicolumn{5}{|l|}{ Poisson (marginal effects) } \\
\hline Days of the case cycle & $\begin{array}{c}2.393 \\
(10.312) \\
{[184]}\end{array}$ & $\begin{array}{c}5.370 \\
(8.461) \\
{[93]}\end{array}$ & $\begin{array}{c}2.205 \\
(11.258) \\
{[129]}\end{array}$ & $\begin{array}{c}5.300 \\
(7.949) \\
{[63]}\end{array}$ \\
\hline
\end{tabular}

Note: Robust standard errors (presented in parentheses) were clustered at the auditor level. Number of observations in brackets. * $\mathrm{p}<0.05, * * \mathrm{p}<0.01$. 


\section{References}

Ahmed, E., \& Braithwaite, V. (2005). Understanding Small Business Taxpayers: Issues of Deterrence, Tax Morale, Fairness and Work Practice. International Small Business Journal, 23(5), 539-568.

Allingham, M. G., \& Sandmo, A. (1972). Income Tax Evasion: A Theoretical Analysis. Journal of Public Economics, 1 (3-4), 323-338.

Andreoni, J. (1990). Impure Altruism and Donations to Public Goods: A Theory of WarmGlow Giving. The Economic Journal, 100(401), 464-477.

Arcos-Holzinger, L., \& Biddle, N. (2016). Behavioural Insights of Tax Compliance: An Overview of Recent Conceptual and Empirical Approaches. Tax and Transfer Policy Institute Working Paper 79.

Ariel, B. (2012). Deterrence and Moral Persuasion Effects on Corporate Tax Compliance: Findings from a Randomized Controlled Trial. Criminology, 50(1), 27-69.

Ariely, D. (2008). Predictably Irrational: The Hidden Forces That Shape our Decisions. New York: HarperCollins.

ATO (2015). Annual Report 2014-15. Report, Australian Taxation Office (ATO), Australian Government, Commonwealth of Australia, Canberra, Australia.

Behavioural Insights Team (2015). Update Report 2013-2015, Cabinet Office, London, United Kingdom.

Behavioural Insights Team (2016). Update Report 2015-2016, Cabinet Office, London, United Kingdom.

Blumenthal, M., Christian, C., Slemrod, J., \& Smith, M. G. (2001). Do Normative Appeals Affect Tax Compliance? Evidence from a Controlled Experiment in Minnesota. National Tax Journal, 54 (1), 125-138.

Bobek, D. D., Hageman, A. M., \& Kelliher, C. F. (2013). Analyzing the role of social norms in tax compliance behavior. Journal of Business Ethics, 115(3), 451-468.

Bott, K., Cappelen, A. W., Sørensen, E. Ø., \& Tungodden, B. (2014). You've Got Mail: A Randomised Field Experiment on Tax Evasion. NHH Norwegian School of Economics Discussion Paper 26/2014.

Braithwaite, J. (2005). Markets in Vice, Markets in Virtue. Oxford University Press on Demand.

Braithwaite, V. (2003). Taxing Democracy. Understanding Tax Avoidance and Evasion. Hants, England: Ashgate Publishing Ltd.

Castro, L., \& Scartascini, C. (2015). Tax Compliance and Enforcement in the Pampas: Evidence from a Field Experiment. Journal of Economic Behavior and Organization, 116, $65-82$. 
Coleman, S. (1997). Income Tax Compliance: A Unique Experiment in Minnesota. Government Finance Review, 13(2), 11-16.

Coleman, S. (2007). The Minnesota Income Tax Compliance Experiment: Replication of the Social Norms Experiment. MPRA Paper No. 5820.

Del Carpio, L. (2013). Are the Neighbors Cheating? Evidence from a Social Norm Experiment on Property Taxes in Peru. Unpublished Manuscript, Princeton University, Princeton, NJ.

Dwenger, N., Kleven, H., Rasul, I., \& Rincke, J. (2016). Extrinsic and Intrinsic Motivations for Tax Compliance: Evidence from a Field Experiment in Germany. American Economic Journal: Economic Policy, 8(3), 203-232.

Dyreng, S. D., Hoopes, J. L., \& Wilde, J. H. (2016). Public Pressure and Corporate Tax Behavior. Journal of Accounting Research, 54(1), 147-186.

Edwards, P. J., Roberts, I., Clarke, M. J., DiGuiseppi, C., Wentz, R., Kwan, I., Cooper, R., Felix, L. M., \& Pratap, S. (2009). Methods to Increase Response to Postal and Electronic Questionnaires. The Cochrane Library.

Fellner, G., Sausgruber, R., \& Traxler, C. (2013). Testing Enforcement Strategies in the Field: Threat, Moral Appeal and Social Information. Journal of the European Economic Association, 11(3), 634-660.

Ferraro, P. J., Miranda, J. J., \& Price, M. K. (2011). The Persistence of Treatment Effects with Norm-Based Policy Instruments: Evidence from a Randomized Environmental Policy Experiment. The American Economic Review, 101(3), 318-322.

Frey, B. S., \& Meier, S. (2004). Social Comparisons and Pro-Social Behavior: Testing "Conditional Cooperation" in a Field Experiment. The American Economic Review, 94(5), $1717-1722$.

Gangl, K., Muehlbacher, S., de Groot, M., Goslinga, S., Hofmann, E., Kogler, C., Antonides, G., \& Kirchler, E. (2013). "How can I Help You?" Perceived Service Orientation of Tax Authorities and Tax Compliance. FinanzArchiv: Public Finance Analysis, 69(4), 487-510.

Gangl, K., Torgler, B., Kirchler, E., \& Hofmann, E. (2014). Effects of Supervision on Tax Compliance: Evidence from a Field Experiment in Austria. Economics Letters, 123(3), 378-382.

Gerber, A. S., \& Green, D. P. (2012). Field Experiments: Design, Analysis, and Interpretation. New York: W.W. Norton.

Hallsworth, M. (2014). The Use of Field Experiments to Increase Tax Compliance. Oxford Review of Economic Policy, 30(4), 658-679.

Hallsworth, M., List, J. A., Metcalfe, R. D., \& Vlaev, I. (2017). The Behavioralist as Tax Collector: Using Natural Field Experiments to Enhance Tax Compliance. Journal of Public Economics, 148, 14-31.

Harju, J., Kosonen, T., \& Ropponen, O. (2014). Do Honest Hairdressers Get a Haircut? Unpublished manuscript. 
Hasseldine, J., Hite, P., James, S., \& Toumi, M. (2007). Persuasive Communications: Tax Compliance Enforcement Strategies for Sole Proprietors. Contemporary Accounting Research, $24(1), 171-194$.

IRS (2016). Tax Gap Estimates for Tax Years 2008-2010. Report, Internal Revenue Service (IRS), USA.

Iyer, G. S., Reckers, P. M., \& Sanders, D. L. (2010). Increasing Tax Compliance in Washington State: A Field Experiment. National Tax Journal, 63(1), 7-32.

Kamleitner, B., Korunka, C., \& Kirchler, E. (2012). Tax Compliance of Small Business Owners: A Review. International Journal of Entrepreneurial Behavior and Research, 18(3), 330-351.

Khan, A. Q., Khwaja, A. I., \& Olken, B. A. (2016). Tax Farming Redux: Experimental Evidence on Performance Pay for Tax Collectors. The Quarterly Journal of Economics, $131(1), 219-271$.

Kleven, H. J., Knudsen, M. B., Kreiner, C. T., Pedersen, S., \& Saez, E. (2011). Unwilling or Unable to Cheat? Evidence from a Tax Audit Experiment in Denmark. Econometrica, $79(3), 651-692$.

List, J. A., \& Metcalfe, R. (2014). Field Experiments in the Developed World: An Introduction. Oxford Review of Economic Policy, 30(4), 585-596.

Martin, R., \& Randal, J. (2008). How is Donation Behaviour Affected by the Donations of Others? Journal of Economic Behavior and Organization, 67(1), 228-238.

McGraw, K. M., \& Scholz, J. T. (1991). Appeals to Civic Virtue Versus Attention to SelfInterest: Effects on Tax Compliance. Law and Society Review, 25(3), 471-498.

Mendoza, J. P., Wielhouwer, J., \& Kirchler, E. (2017). The Backfiring Effect of Auditing on Tax Compliance. WU International Taxation Research Paper Series No. 2017-05.

OECD (2014). Working Smarter in Tax Debt Management. Report, Organisation for Economic Co-operation and Development (OECD) Publishing, Paris.

Office of the Revenue Commissioners (2017). Applying Behavioural Science in Tax Administration - A Summary of Lessons Learned. Report, Office of the Revenue Commissioners, Statistics and Economic Research Branch, Ireland.

Ortega, D., \& Scartascini, C. (2015). Don't Blame the Messenger: A Field Experiment on Delivery Methods for Increasing Tax Compliance. IDB Working Paper No. 627.

Perez-Truglia, R., \& Troiano, U. (2015). Shaming Tax Delinquents: Theory and Evidence from a Field Experiment in the United States. National Bureau of Economic Research Working Paper No. 21264.

Pomeranz, D. (2015). No Taxation Without Information: Deterrence and Self-Enforcement in the Value Added Tax. The American Economic Review, 105(8), 2539-2569.

Schwartz, R. D., \& Orleans, S. (1967). On Legal Sanctions. The University of Chicago Law Review, 34(2), 274-300. 
Seyranian, V., Sinatra, G. M., \& Polikoff, M. S. (2015). Comparing Communication Strategies for Reducing Residential Water Consumption. Journal of Environmental Psychology, 41, $81-90$.

Shimeles, A., Gurara, D. Z., \& Woldeyes, F. (2017). Taxman's Dilemma: Coercion or Persuasion? Evidence from a Randomized Field Experiment in Ethopia. American Economic Review, 107(5), 420-424.

Slemrod, J. (2007). Cheating Ourselves: The Economics of Tax Evasion. Journal of Economic Perspectives, 21(1), 25-48.

Slemrod, J. (2016). Tax Compliance and Enforcement: An Overview of New Research and Its Policy Implications. Unpublished manuscript.

Slemrod, J., Blumenthal, M., \& Christian, C. (2001). Taxpayer Response to an Increased Probability of Audit: Evidence from a Controlled Experiment in Minnesota. Journal of Public Economics, $79(3)$, 455-483.

STA (2005). Right from the Start: Research and Strategies. Report, Swedish Tax Agency (STA), Solna.

Tan, L. M., \& Liu, X. (2016). SMEs Tax Compliance: A Matter of Trust? Australian Tax Forum, $31(3), 527-554$.

Thaler, R. H., \& Sunstein, C. R. (2008). Nudge: Improving Decisions about Health, Wealth, and Happiness. New Haven, CT: Yale University Press.

Thomas, K. D. (2013). Presumptive Collection: A Prospect Theory Approach to Increasing Small Business Tax Compliance. Tax Law Review, 67(2013), 111-168.

Tiefenbeck, V., Staake, T., Roth, K., \& Sachs, O. (2013). For Better or for Worse? Empirical Evidence of Moral Licensing in a Behavioral Energy Conservation Campaign. Energy Policy, 57, 160-171.

Torgler, B. (2004). Moral Suasion: An Alternative Tax Policy Strategy? Evidence from a Controlled Field Experiment in Switzerland. Economics of Governance, 5 (3), 235-253.

Torgler, B. (2007). Tax Compliance and Tax Morale: A Theoretical and Empirical Analysis. Edward Elgar Publishing.

Torgler, B. (2013). A Field Experiment in Moral Suasion and Tax Compliance Focusing on Underdeclaration and Overdeduction. FinanzArchiv: Public Finance Analysis, 69(4), 393411.

Wenzel, M. (2005a). Misperceptions of Social Norms about Tax Compliance: From Theory to Intervention. Journal of Economic Psychology, 26(6), 862-883.

Wenzel, M. (2005b). Motivation or Rationalisation? Causal Relations between Ethics, Norms and Tax Compliance. Journal of Economic Psychology, 26 (4), 491-508.

Wenzel, M. (2006). A Letter from the Tax Office: Compliance Effects of Informational and Interpersonal Justice. Social Justice Research, 19(3), 345-364. 
Wenzel, M., \& Taylor, N. (2004). An Experimental Evaluation of Tax-Reporting Schedules: A Case of Evidence-Based Tax Administration. Journal of Public Economics, 88(12), 27852799 .

Woodward, L., \& Tan, L. M. (2015). Small Business Owners' Attitudes Toward GST Compliance: A Preliminary Study. Australian Tax Forum, 30(3), 517-549. 


\section{Appendix A - Trial I: Letters}

\section{TRIAL I: CONTROL}

|||||||||||||||||||||||||||||||||||||

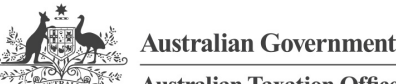

$<$ Title $><$ First Name $>$ Surname $>$

$<$ Address line 1>

$<$ Address line $2>$

$<$ Address line $3>$

$<$ CITY $><$ STATE $><$ POSTCODE $>$

Our reference:

Phone:

$A B N$ :

\section{You need to review your GST refund}

, Your GST refund claim may be incorrect

, Review your records and revise any claims by 30 November 2015

Dear $<$ First name $><$ Sir/Madam $>$

Your goods and services tax (GST) refund has been selected for review. Our data modelling indicates that your refund claim may be incorrect. You need to review your GST refund for the tax period from $<$ tax period from $>$ to $<$ tax period to $>$

\section{What you need to do}

Check the amounts reported on your activity statement and compare these with the information and calculations you used in preparing your activity statement. Specific areas you may want to review include:

, incorrect transposition of figures

, invoices that do not include GST

, private expenses that may have been included.

If you haven't made an error or omission, you don't need to do anything further. Please keep your GST records handy as we can ask for further information to confirm your claim.

If you have made an error or omission, please revise your activity statement by 30 November 2015, and no penalties will apply. You will, however, need to pay any GST and interest owing.

We appreciate your cooperation in paying the right amount of GST to support important services in your <state $><$ territory $>$.

Yours $<$ sincerely $><$ faithfully $>$

<Deputy Commissioner's Name>

Deputy Commissioner of Taxation

\section{FIND OUT MORE}

To find out more about correcting

activity statement errors, go to

ato.gov.au and search for

Correct an instalment or

business activity statement'.

If you have any questions, please phone [phone number] between $.00 \mathrm{am}$ and $6.00 \mathrm{pm}$. Monday to

Friday. 
TRIAL I: TREATMENT 1

||||||||||||||||||||||||||||||||||||

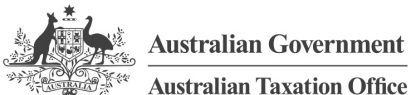

$<$ Title $><$ First Name $>$ Surname $>$

$<$ Address line $1>$

$<$ Address line $2>$

$<$ Address line $3>$

$<$ CITY $><$ STATE $><$ POSTCODE $>$

Our reference:

Phone:

ABN:

12 November 2015

\section{You need to review your GST refund}

, Your GST refund claim may be incorrect

, Review your records and revise any claims by 14 December 2015

Dear $<$ First name $><$ Sir/Madam $>$

FIND OUT MORE

Your goods and services tax (GST) refund has been selected for review. Our data modelling indicates that your refund claim may be incorrect. You need to review your GST refund for the tax period from <tax period from> to $<$ tax period to $>$.

What you need to do

Check the amounts reported on your activity statement and compare these with the information and calculations you used in preparing your activity statement. Specific areas you may want to review include:

To find out more about correcting activity statement errors, go to

ato.gov.au and search for

'Correct an instalment or

business activity statement'.

If you have any questions, please phone [phone number] between $8.00 \mathrm{am}$ and $6.00 \mathrm{pm}$, Monday to

Friday.

> incorrect transposition of figures

, invoices that do not include GST

, private expenses that may have been included.

If you haven't made an error or omission, you don't need to do anything further. Please keep your GST records handy as we can ask for further information to confirm your claim.

If you have made an error or omission, please revise your activity statement by 14 December 2015, and no penalties will apply. You will, however, need to pay any GST and interest owing.

We appreciate your cooperation in paying the right amount of GST to support important services in your <state $><$ territory $>$.

Yours $<$ sincerely $><$ faithfully $>$

$<$ Deputy Commissioner's Name $>$

Deputy Commissioner of Taxation 
TRIAL I: TREATMENT 2

||||||||||||||||||||||||||||||||||||

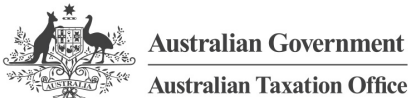

$<$ Title $><$ First Name $>$ Surname $>$

$<$ Address line $1>$

$<$ Address line 2>

$<$ Address line $3>$

$<$ CITY $><$ STATE $><$ POSTCODE $>$

Our reference:

Phone:

ABN:

12 November 2015

\section{Our tax system works because people do the} right thing

, Your GST refund claim may be incorrect
, Review your records and revise any claims by 30 November 2015

Dear $<$ First name $><$ Sir/madam $>$

Your goods and services tax (GST) refund has been selected for review. Our data modelling indicates that your refund claim may be incorrect. You need to review your GST refund for the tax period from $<$ tax period from $>$ to $<$ tax period to $>$.

What you need to do

Check the amounts reported on your activity statement and compare these with the information and calculations you used in preparing your activity statement. Specific areas you may want to review include:

, incorrect transposition of figures

, invoices that do not include GST

, private expenses that may have been included.

If you haven't made an error or omission, you don't need to do anything further. Please keep your GST records handy as we can ask for further information to confirm your claim.

If you have made an error or omission, please revise your activity statement by 30 November 2015, and no penalties will apply. You will, however, need to pay any GST and interest owing.

We appreciate your cooperation in paying the right amount of GST to support important services in your <state $><$ territory $>$.

Yours $<$ sincerely $><$ faithfully $>$

<Deputy Commissioner's Name>

Deputy Commissioner of Taxation

\section{FIND OUT MORE}

To find out more about correcting activity statement errors, go to

ato.gov.au and search for

'Correct an instalment or

business activity statement'.

If you have any questions, please phone [phone number] between $8.00 \mathrm{am}$ and $6.00 \mathrm{pm}$, Monday to

Friday. 
TRIAL I: TREATMENT 3

||||||||||||||||||||||||||||||||||||

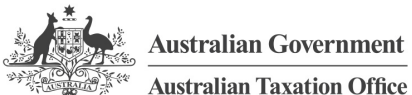

$<$ Title $><$ First Name $>$ Surname $>$

$<$ Address line $1>$

$<$ Address line 2>

$<$ Address line $3>$

$<$ CITY $><$ STATE $><$ POSTCODE $>$

Our reference:

Phone:

ABN:

12 November 2015

\section{You need to review your GST refund}

, Your GST refund claim may be incorrect

, Review your records and revise any claims by 30 November 2015

Dear $<$ First name $><$ Sir/Madam $>$

FIND OUT MORE

Your goods and services tax (GST) refund has been selected for review. Our data modelling indicates that your refund claim may be incorrect. You need to review your GST refund for the tax period from <tax period from> to $<$ tax period to $>$.

What you need to do

Check the amounts reported on your activity statement and compare these with the information and calculations you used in preparing your activity statement. Specific areas you may want to review include:

To find out more about correcting activity statement errors, go to

ato.gov.au and search for

'Correct an instalment or

business activity statement'.

If you have any questions, please phone [phone number] between $8.00 \mathrm{am}$ and $6.00 \mathrm{pm}$, Monday to

Friday.

> incorrect transposition of figures

, invoices that do not include GST

, private expenses that may have been included.

If you haven't made an error or omission, you don't need to do anything further. Please keep your GST records handy as we can ask for further information to confirm your claim.

If you have made an error or omission, please revise your activity statement by 30 November 2015, and no penalties will apply. You will, however, need to pay any GST and interest owing.

We appreciate your cooperation in paying the right amount of GST to support important services in your <state $><$ territory $>$.

Yours $<$ sincerely $><$ faithfully $>$

$<$ Deputy Commissioner's Name

Deputy Commissioner of Taxation 
TRIAL I: TREATMENT 4

||||||||||||||||||||||||||||||||||||

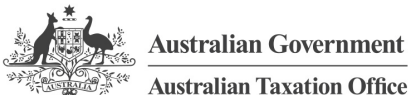

$<$ Title $><$ First Name $>$ Surname $>$

$<$ Address line $1>$

$<$ Address line $2>$

$<$ Address line $3>$

$<$ CITY $><$ STATE $><$ POSTCODE $>$

Our reference:

Phone:

ABN:

12 November 2015

\section{You need to review your GST refund}

, Your GST refund claim may be incorrect

, Review your records and revise any claims by 30 November 2015

Dear $<$ First name $><$ Sir/Madam $>$

FIND OUT MORE

Your goods and services tax (GST) refund has been selected for review. Our data modelling indicates that your refund claim may be incorrect. You need to review your GST refund for the tax period from <tax period from> to $<$ tax period to $>$.

What you need to do

Check the amounts reported on your activity statement and compare these with the information and calculations you used in preparing your activity statement. Specific areas you may want to review include:

> incorrect transposition of figures

, invoices that do not include GST

, private expenses that may have been included.

If you haven't made an error or omission, you don't need to do anything further. Please keep your GST records handy as we can ask for further information to confirm your claim.

If you have made an error or omission, please revise your activity statement by 30 November 2015, and no penalties will apply. You will, however, need to pay any GST and interest owing.

To find out more about correcting activity statement errors, go to

ato.gov.au and search for

'Correct an instalment or

business activity statement'.

If you have any questions, please phone [phone number] between $8.00 \mathrm{am}$ and $6.00 \mathrm{pm}$, Monday to Friday.

DID YOU KNOW?

Many charities rely on the generosity of supporters for some or all of their funding. All donations of $\$ 2$ or more are tax deductible.

For more information, go to ato.gov.au and search for 'Gifts and donations'.

We appreciate your cooperation in paying the right amount of GST to support important services in your <state ><territory>

Yours $<$ sincerely $><$ faithfully $>$

<Deputy Commissioner's Name>

Deputy Commissioner of Taxation 


\title{
Appendix B - Trial II: Phone Script and Letters
}

\author{
Trial II: Control 2A (Desk Audit Telephone Script)
}

(...) "As at today, there is a debt on $<$ your $><$ your clients $>$ account for the $\$<$ amount $>$, which may increase as a result of this audit. I need to make you aware of this and the payment options available to $<$ you $><$ your client $>$ to pay this debt". (...)

(...) "If $<$ you $><$ your client $>$ are unable to pay this amount in full, a payment plan may be an option. If $<$ you $><$ your client $>$ would like to know more about this option, contact our Debt area on [phone number] or visit the ato.gov.au website." (...)

\section{Trial II: Treatment 2A (Desk Audit Telephone Script)}

\section{CLIENT}

(...) "As at today, there is a debt on your account for the $\$<$ amount $>$, which may increase as a result of this audit. I need to make you aware of this and the payment options available to you to pay this debt. If you are unable to pay this amount in full, an interim payment plan may be an option.

You can call the right area of the ATO on [phone number] between 8.00am and 6.00pm weekdays. If you explain your circumstances and you're trying to do the right thing, we're committed to helping you where possible. The officer you speak to will need to know more about your financial situation and your circumstances so they can work with you to set up a payment plan that is manageable for you. I can transfer you now." (...) (warm transfer to Debt Early Intervention)

\section{TAX AGENT}

(...) "As at today, there is a debt on your clients account for the $\$<$ amount $>$, which may increase as a result of this audit. I need to make you aware of this and the payment options available to your client to pay this debt. If your client is unable to pay this amount in full, an interim payment plan may be an option.

Your client can call the right area of the ATO on [phone number] between 8.00am and 6.00pm weekdays. If your client explains their circumstances and your client is trying to do the right thing, we're committed to helping your client where possible. The officer your client speaks to will need to know more about their financial situation and their circumstances so they can work with your client to set up an interim payment plan that is manageable for your client." $(\ldots)$ 


\section{Confirmation of your employer obligations audit}

Dear <Recipient title, Recipient surname OR Sir/Madam>

As discussed on $<\mathrm{DD}$ Month CCYY> with you [or] your tax representative, we are checking your compliance with your employer obligations.

[Delete options in table that are not required.]

Pay as you go (PAYG) withholding

$<\mathrm{DD}$ Month $\mathrm{CCYY}>$ to $<\mathrm{DD}$ Month $\mathrm{CCYY}>$

Super guarantee (SG)

<DD Month CCYY> to <DD Month CCYY>

We will check that you have:

correctly withheld the PAYG withholding amounts from salary, wages and other payments

correctly reported the withheld amounts to us in your activity statement, and

complied with your super guarantee obligations.

[Insert only if there is an existing tax liability]

Our records show you have an existing tax debt. We will discuss payment of this debt during the audit.

\section{PAYG withholding}

The amounts reported by your employees in their $\langle\mathrm{CCY} Y\rangle<$ and $>\langle\mathrm{CCY} Y\rangle$ tax returns are more than the amounts you reported to us.

[*Include one of the following options, delete those not applicable*]

[Option 1 - Insert for overdue activity statements and FTN cases]

We discussed your overdue activity statement $<s>$. The overdue activity statement $<s>$ should be lodged by the date $<s>$ shown in the enclosed form. If you have other activity statements that fall due during the audit period, you need to lodge these on time.

If you don't lodge it [or] them by the date<s> shown in the enclosed form<s>, we may without further notice, determine the PAYG withholding amount $<\mathrm{s}>$ you withheld based on information available to us. You will be liable to a penalty equal to $75 \%[$ or] $90 \%$ of the amount $<$ s $>$ withheld.

[Option 2 -Insert for under-notified cases]

We discussed the under-notified PAYG withholding amount $<s>$ you reported to us. You need to lodge $<\mathrm{a}>$ revised activity statement $<\mathrm{s}>$ to correct this for the period $<\mathrm{s}>$ and by the date $<\mathrm{s}>$ shown in the enclosed form.

[Option 3 - Insert for overdue PAYG payment summary statement]

As discussed, your overdue PAYG payment summary statement for $\langle C C Y Y>$ and $\langle C C Y Y\rangle$ financial years should be lodged by $\angle D D$ Month CCYY $>$. If you have other payment summary statements that fall due during the audit period, you need to lodge these on time.

[“End of options*]

Superannuation guarantee

[*Include one of the following options, delete those not applicable*]

[Option 1 - Select where SG non-compliance is not confirmed]

If you have not complied with your superannuation guarantee obligations for the period <SG POR

start date> to <SG POR end date>, you are liable for the superannuation guarantee charge (SGC) and additional SGC, by way of penalty, up to $200 \%$ of the SGC.

You need to immediately lodge a Superannuation guarantee charge statement - quarterly and pay the SGC to us. If you lodge the statement<s> we may reduce the penalty to $25 \%$ of the SGC. For further information about how to complete and lodge SGC statements, go to our website, ato.gov.au/super/superforemployers.

If you don't lodge the statement $<$ s>, we may without further notice, issue $<$ a $>$ default SGC assessment<s> based on information available to us. You will then be liable to additional SGC, by way of penalty, up to $200 \%$ of the SGC. 
Will <ReturnUnclaimedAddressBarCode>

$<$ Title $><$ First Name $><$ Middle Name $><$ Surname $>$

$<$ Suffix $><$ Organisation $>$

$<$ Address Line 1>

$<$ Address Line 2>

$<$ LOCALITY > <STATE > <POSTCODE >

$<$ COUNTRY $>$

Reply to: <address>

Our reference: <our reference>

Contact officer: <Contact officer>

Phone: <phone number>

Fax: <fax number>

$<$ Case ID $\rangle$ : $\quad\langle$ Case Id $>$

$<A B N>$ : $\quad<A B N>$

$<$ Letter date>

\section{Notice of audit - employer obligations}

Dear $<$ Title $><$ Surname $><$ Sir/Madam $>$

We are checking your compliance with your employer obligations as discussed with $<$ you $><$ your tax representative $>$ on <DD Month CCYY>.

We will check that you have:

- correctly withheld the PAYG withholding amounts from salary, wages and other payments

- correctly reported PAGW withholding amounts to us in your activity statement, and

- complied with your super guarantee obligations.

[Insert only if there is an existing tax liability]

Our records show you have an existing tax debt. We will discuss payment of this debt with you during the audit.

\section{What you need to do}

\begin{tabular}{l|l|l|}
\hline By <DD Month CCYY> & $\begin{array}{l}\text { Complete and send the enclosed Employer obligations audit form } \\
\text { to us }\end{array}$ \\
\hline By <DD Month CCYY> & Lodge the documents shown in the enclosed Lodgment Planner
\end{tabular}

If you have any questions, please phone $\mathbf{X X X X X X X X X}$ between 8.00am and 5.00pm, Monday to Friday and ask for $<$ Compliance officer name $>$ on extension $<$ Compliance officer extension number>.

Yours $<$ sincerely $><$ faithfully $>$

<Deputy Commissioner's Name>

Deputy Commissioner of Taxation

cc. $<$ taxpayer $><$ tax representative $>$ 


\section{Appendix C - List of Control Variables}

\section{Trial I}

Potential control variables:

- The total number of business activity statements lodged in the 2014 - 2015 financial year

- The number of net GST payable business activity statements in the 2014 - 2015 financial year

- The number of net GST refunds lodged in the 2014 - 2015 financial year

- The number of net payable business activity statements (if any) in the $2014-2015$ financial year

- The number of net refund business activity statements (if any) in the 2014 - 2015 financial year

- The total net GST payable (if any) in the 2014 - 2015 financial year

- The total amount of net GST refundable in the 2014 - 2015 financial year

- The total net payable amount (if any) in the 2014 - 2015 financial year

- The total net refund amount (if any) in the 2014 - 2015 financial year

- A variable indicating the risk group (high or low risk) based on a risk score of the ATO

- A variable indicating the accounting method used - Cash or non-cash (accrual) ${ }^{16}$

- Days between the original business activity statement lodgement date and the last business activity statement lodgement date

- Days between lodgements

- Variables indicating the lodgement $\operatorname{method}^{17}$

- Variables indicating the lodgement cycle for GST reporting (monthly, quarterly or annual)

- Market segment based on an internal ATO definition ${ }^{18}$

- Client type (Company, Individual, Partnership, Superannuation Fund, Trust)

- State

\footnotetext{
${ }^{16}$ https: //www . ato.gov.au/Business/GST/Accounting-for-GST-in-your-business/Choosing-anaccounting-method/

${ }^{17}$ The method in which the business activity statements and revisions were lodged by enterprises. TAP Tax Agent Portal (exclusive lodgement medium available to tax agents). BP - Business Portal (Electronic lodgement via exclusive business portal). CDC - Corporate Data Capture (Paper lodgement). TAP-BSP BAS Agent Portal (Extension of the Tax Agent portal but for BAS agents). ESD - Electronic Service Delivery (Being phased out). ATO Online - internet lodgement via ATO Online services. GOV Reports - Tax Agent software (non ATO). OTH - Internal. Xero Practice manager Tax - Lodged via Xero 'cloud' based accounting software.

${ }^{18} \mathrm{NFP}$ - Not for profit enterprise; the NFP segment is made up of non-profit organisations including tax exempt institutions, registered charities, health and community service organisations and non-profit companies. MIC - Micro enterprise, Economic groups and single entities with an annual turnover less than $\$ 2$ million. SME - Small/Medium enterprise, Economic groups and single entities with an annual turnover greater than $\$ 2$ million and less than $\$ 250$ million. LGE - Large market enterprise, economic groups and single entities with an annual turnover greater than $\$ 250$ million.
} 
- Industry code based on Australian and New Zealand Standard Industrial Classification $(\text { ANZSIC })^{19}$

- Variables indicating whether an income tax return was lodged in the financial years 2010 - 2011, 2011 - 2012, 2012 - 2013, 2013 - 2014, 2014 - 2015

- The total business income for the financial years 2010 - 2011, 2011 - 2012, 2012 - 2013, 2013 - 2014, 2014 - 2015

- The total business expenses for the financial years 2010 - 2011, 2011 - 2012, 2012 - 2013, 2013 - 2014, 2014 - 2015

- The total profit or loss for the financial years 2010 - 2011, 2011 - 2012, 2012 - 2013, 2013 - 2014, $2014-2015$

\section{Trial II}

Potential control variables:

- Amount owed by the taxpayer at the start of the case (manual entry)

- Number of employees

- Total business income

- Market segment (not for profit, micro, small/medium, large)

- Industry code based on Australian and New Zealand Standard Industrial Classification (ANZSIC)

\footnotetext{
${ }^{19}$ http://www.abs.gov.au/AUSSTATS/abs@.nsf/DetailsPage/1292.0.55.0022006?0penDocument
} 